\title{
Unusual Activation Pathways of Amines in the Reactions with Molybdenum Pentachloride
}

\author{
Niccolò Bartalucci, ${ }^{a}$ Marco Bortoluzzi, ${ }^{b}$ Fabio Marchetti, ${ }^{*}, a$ Guido Pampaloni, ${ }^{a}$ Silvia Schoch, ${ }^{a}$ Stefano Zacchini ${ }^{*}, c$ \\ ${ }^{a}$ Università di Pisa, Dipartimento di Chimica e Chimica Industriale, Via Moruzzi 13, I-56124 Pisa, Italy. Tel: +39 050 \\ 2219245.E-mail: fabio.marchetti1974@unipi.it.Webpage: http://www.dcci.unipi.it/fabio-marchetti.html. \\ ${ }^{b}$ Università di Venezia Ca' Foscari, Dipartimento di Scienze Molecolari e Nanosistemi, Via Torino 155, I-30170 Mestre (VE), \\ Italy. \\ c Università di Bologna, Dipartimento di Chimica Industriale "Toso Montanari”, Viale Risorgimento 4, I-40136 \\ Bologna, Italy.E-mail: stefano.zacchini@unibo.it.Webpage: https://www.unibo.it/sitoweb/stefano.zacchini.
}

\begin{abstract}
This submission was created using the RSC Article Template (DO NOT DELETE THIS TEXT) (LINE INCLUDED FOR SPACING ONLY - DO NOT DELETE THIS TEXT)
\end{abstract}

\begin{abstract}
The 1:1 molar reactions at room temperature of $\mathrm{MoCl}_{5}$ with aliphatic amines were investigated in dichloromethane. Pyrrolidine, diethylamine and dibenzylamine underwent dehydrogenative oxidation when allowed to react with $\mathrm{MoCl}_{5}$; the compounds $\left.\left[\mathrm{MoCl}_{5}\left\{\mathrm{NCH}_{(\mathrm{CH}}\right)_{3}\right\}\right]$, 1, and $\left[\mathrm{CH}_{3} \mathrm{CH}=\mathrm{NHEt}\right]\left[\mathrm{MoOCl}_{4}\right]$, 2, were isolated in moderate to low yields from $\mathrm{MoCl}_{5} /$ pyrrolidine and $\mathrm{MoCl}_{5} / \mathrm{NHEt}_{2}$, respectively. The chlorideamide complex $\left[\mathrm{MoCl}_{4}\left(\mathrm{NEt}_{2}\right)\right]$, 3, was afforded in $65 \%$ yield from $\mathrm{MoCl}_{5}$ and $\mathrm{Et}_{2} \mathrm{NSiMe}_{3}$. The interaction of $\mathrm{MoCl}_{5}$ with $\mathrm{Me}_{2} \mathrm{NSiMe}_{3}$ was accompanied by activation of the solvent, and the complexes $\left[\mathrm{MoCl}_{3}\left(\mathrm{NMe}_{2}\right)\left(\kappa^{2}-\mathrm{Me}_{2} \mathrm{NCH}_{2} \mathrm{NMe}_{2}\right)\right], 4 \mathbf{a}$, and $\left[\mathrm{MoCl}_{3}\left(\mathrm{NMe}^{2}\left(\kappa^{2}-\mathrm{Me}_{2} \mathrm{NCH}_{2} \mathrm{NMe}_{2}\right)\right]\right.$, $\mathbf{4 b}$, co-crystallized from the reaction mixture. The reactions of $\mathrm{MoCl}_{5}$ with a series of primary amines afforded mixtures of products, and the $\mathrm{Mo}(\mathrm{VI})$ chloride imido complexes $\left[\mathrm{MoCl}_{4}(\mathrm{NR})\right]_{2}\left(\mathrm{R}=\mathrm{Cy}, \mathbf{5 a} ;{ }^{\mathrm{t}} \mathrm{Bu}, \mathbf{5 b}\right)$ were isolated in $c a .40 \%$ yield from $\mathrm{MoCl}_{5} / \mathrm{NH}_{2} \mathrm{R}\left(\mathrm{R}=\mathrm{Cy},{ }^{\mathrm{t}} \mathrm{Bu}\right) . \mathrm{C}-\mathrm{H}$ bond activation may be viable in the reactions of $\mathrm{MoCl}_{5}$ with tertiary amines: the compounds $\left[\left(\mathrm{CH}_{2} \mathrm{Ph}\right)_{2} \mathrm{~N}=\mathrm{CHPh}_{2}\left[\mathrm{MoCl}_{6}\right] \cdot \mathrm{CH}_{2} \mathrm{Cl}_{2}, \mathbf{6}\right.$, and $\left[\mathrm{NHEt}_{3}\right]_{2}\left[\mathrm{Mo}_{2} \mathrm{Cl}_{10}\right]$, 7, were obtained from $\mathrm{MoCl}_{5} /$ tribenzylamine and $\mathrm{MoCl}_{5} /$ triethylamine, respectively. Pyrrolidine and tribenzylamine underwent analogous activation pathways when allowed to react with $\left[\mathrm{MoCl}_{3}\left\{\mathrm{OCH}\left(\mathrm{CF}_{3}\right)_{2}\right\}\right]_{2}$ in the place of $\mathrm{MoCl}_{5}$. The isolated metal products were characterized by analytical and spectroscopic techniques, in addition the structures of $\mathbf{1}, \mathbf{2}, \mathbf{4}, \mathbf{5 a}, \mathbf{6} \cdot \mathrm{CH}_{2} \mathrm{Cl}_{2}$ and $\mathbf{7}$ were ascertained by single crystal X-ray diffraction studies. The organic products were identified by NMR and GC-MS after hydrolysis of the reaction mixtures. DFT calculations were carried out in order to assist the IR assignments, and clarify structural and mechanistic aspects.
\end{abstract}

\section{Introduction}

Homoleptic chlorides of high valent transition metals have been employed as effective catalytic precursors in a variety of organic reactions. ${ }^{1}$ These compounds typically manifest their strong acidic nature towards primary and secondary amines, affording amidoderivatives via aminolysis reactions. This behaviour has been well established with reference to group 4 metal tetrahalides, ${ }^{2}$ and $\mathrm{Nb}$ and Ta pentahalides. ${ }^{3}$ Nevertheless alternative reaction pathways may be working, and this is probably the reason why mixed chloride amide complexes have been more frequently prepared by treatment of the parent metal chlorides with lithium amides. ${ }^{4}$ More precisely, when the metal chloride is allowed to react with an excess of primary amine, the formation of metal-amido species (M-NHR) may be followed by proton abstraction affording imido ligands (M=NR). This usually takes place without a change in the oxidation state of the metal centre. ${ }^{2 e, 3 d, 5}$ Alternatively, imido derivatives have been obtained by the addition of a suitable base to the metal chloride/amine system. ${ }^{3 \mathrm{c}, 6}$ In some cases, high valent transition metal chlorides act as single electron oxidant reagents towards amines, the amines possibly converting into the relevant iminium cations. ${ }^{3 a, 7}$ This kind of reactivity usually regards tertiary amines, and, for instance, the redox interaction between $\mathrm{TiCl}_{4}$ and trialkylamines constitutes an efficient catalytic system serving diverse organic transformations, such as the $\mathrm{C}-\mathrm{C}$ coupling of esters, ${ }^{8}$ the synthesis of 2,5diarylpyrroles ${ }^{9}$ and $\alpha, \beta$-unsaturated carbonyl compounds. ${ }^{10}$ Being involved with the coordination chemistry of group 6 chlorides, we have recently elucidated the reactions of $\mathrm{WCl}_{6}$ with limited amounts of tribenzylamine and triphenylamine, respectively. Both the reactions proceed with single electron transfer from the organic reactant to the metal centre, followed by $\mathrm{C}-\mathrm{H}$ bond activation and intermolecular hydrogen migration. ${ }^{11}$
In this overall scenario, information on the direct interaction of molybdenum pentachloride, $\mathrm{MoCl}_{5}$, with amines still remain rather sparse in the literature. Simple coordination adducts were claimed to be formed by combination of $\mathrm{MoCl}_{5}$ with tertiary aliphatic amines. ${ }^{12}$ On the other hand, based on elemental analyses, it was suggested that the reactions with an excess of primary and secondary aliphatic amines afforded mixed chloride amide complexes, as expected from aminolysis processes. $^{12}$ Later on, Nielson reported the $\mathrm{Mo}(\mathrm{V})$ compound $\left[\mathrm{Mo}\left(\mathrm{NCMe}_{3}\right)\left(\mathrm{NHCMe}_{3}\right) \mathrm{Cl}_{2}\left(\mathrm{NH}_{2} \mathrm{CMe}_{3}\right)\right]_{2}$, containing amino, amido and imido groups, as the prevalent product of the reaction of $\mathrm{MoCl}_{5}$ with six equivalent of tert-butylamine in benzene. ${ }^{5}$ Similarly, $\left[\mathrm{Mo}\left(\mathrm{NCMe}_{3}\right) \mathrm{Cl}_{3}\left(\mathrm{NH}_{2} \mathrm{CMe}_{3}\right)\right]_{2}$ was obtained from $\mathrm{MoCl}_{5}$ and $\mathrm{Me}_{3} \mathrm{SiNHCMe}_{3}$ (1:2 ratio). ${ }^{5}$

In the present paper, we describe the results of our investigation on the reactivity of $\mathrm{MoCl}_{5}$ with a selection of primary, secondary and tertiary aliphatic amines, including $\mathrm{N}$ (trimethylsilyl)dialkylamines, in a weakly coordinating solvent. A comparison with the analogous reactions of the $\mathrm{Mo}(\mathrm{V})$ chloride alkoxide compound $\mathrm{MoCl}_{3}\left[\mathrm{OCH}\left(\mathrm{CF}_{3}\right)_{2}\right]_{2}{ }^{13}$ will be discussed.

\section{Results and Discussion}

1. Reactions of $\mathrm{MoCl}_{5}$ with secondary amines.

We were interested in the synthesis of $\mathrm{Mo}(\mathrm{V})$ mixed chloride amide compounds of the type $\mathrm{MoCl}_{\mathrm{x}}\left(\mathrm{NR}_{2}\right)_{5-\mathrm{x}}$. According to the information available in the literature, ${ }^{12}$ we performed the reactions of $\mathrm{MoCl}_{5}$ with a selection of secondary aliphatic amines. Surprisingly, these reactions did not furnish the expected products. When $\mathrm{MoCl}_{5}$ was allowed to react with pyrrolidine, diethylamine and dibenzylamine, in 1:1 molar ratios in $\mathrm{CH}_{2} \mathrm{Cl}_{2}$, mixtures of metal products were obtained which could not be fully identified (vide infra). In order to understand the destiny of the organic material, we treated the respective solid residues with $\mathrm{CDCl}_{3} /$ water. $^{14,15}$ Subsequent NMR 
analyses pointed out the prevalent formation of dehydrogenative oxidation products (Scheme 1). More in detail, almost complete conversion of pyrrolidine to pyrroline was ascertained, while ca. $50 \%$ of dibenzylamine was found converted into the relevant imine. Pyrroline was detected in its monomeric form, and no evidence for oligomerization was found. ${ }^{16}$ Acetaldehyde was the only product detected from $\mathrm{MoCl}_{5} / \mathrm{NHEt}_{2}$, the aldehyde presumably generating from $N$-ethylidene ethanamine in hydrolytic conditions (see below)

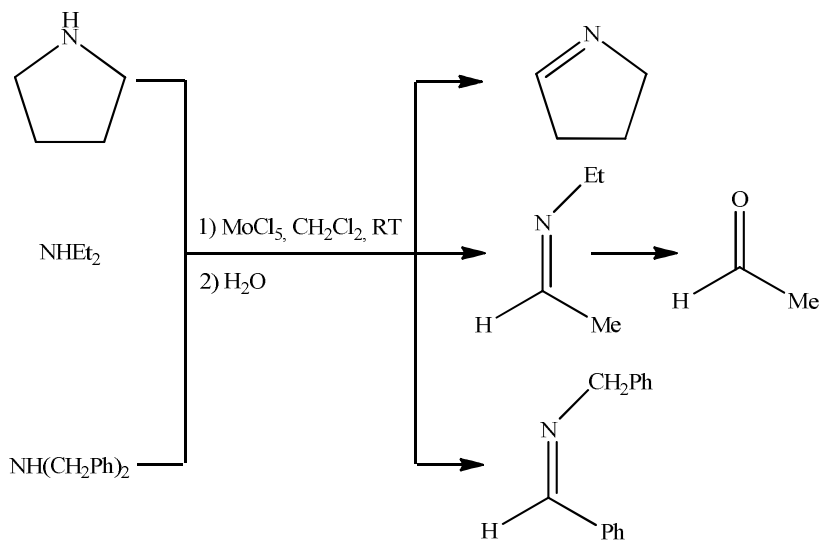

Scheme 1. $\mathrm{MoCl}_{5}$-directed oxidation of dialkylamines.

Several attempts were conducted in order to isolate metal products from the highly moisture sensitive reaction systems. Hence, $\left[\mathrm{MoCl}_{5}\left\{\mathrm{NCH}\left(\mathrm{CH}_{2}\right)_{3}\right\}\right], \mathbf{1}$, and minor amounts of $\left[\mathrm{CH}_{3} \mathrm{CH}=\mathrm{NHEt}\right]\left[\mathrm{MoOCl}_{4}\right], 2$, were isolated as crystalline materials from $\mathrm{MoCl}_{5} /$ pyrrolidine and $\mathrm{MoCl}_{5} / \mathrm{NHEt}_{2}$, respectively, and X-ray characterized (scheme 2).

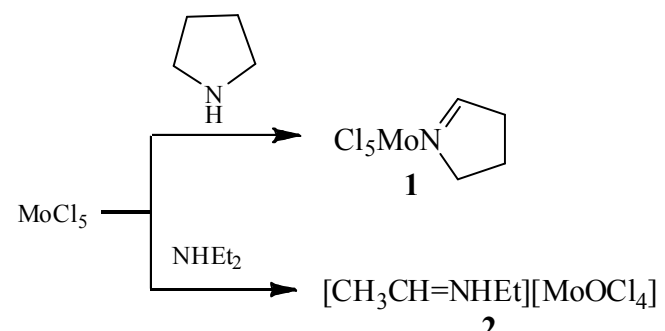

Scheme 2. Isolation of metal complexes from the reactions of $\mathrm{MoCl}_{5}$ with pyrrolidine and diethylamine.

Compounds $\mathbf{1}$ and $\mathbf{2}$ contain a pyrroline ligand and a $\mathrm{N}$-ethylidenium ethanamine cation, respectively, coherently with the NMR analyses on the corresponding hydrolyzed reaction mixtures. In particular, the detection of $[\mathrm{MeCH}=\mathrm{NHEt}]^{+}$as found in $\mathbf{2}$ confirms the occurrence of dehydrogenative oxidation of diethylamine by means of $\mathrm{MoCl}_{5}$ (Scheme 1); the presence of the oxido ligand within the counterion appears to be the result of fortuitous hydrolysis of $\mathrm{Mo}-\mathrm{Cl}$ bonds in the course of the crystallization procedure. ${ }^{17}$ Views of the X-ray structures of $\mathbf{1}$ and $\mathbf{2}$ are given in Figures 1 and 2, the relevant bonding parameters being reported in Tables 1 and 2 .

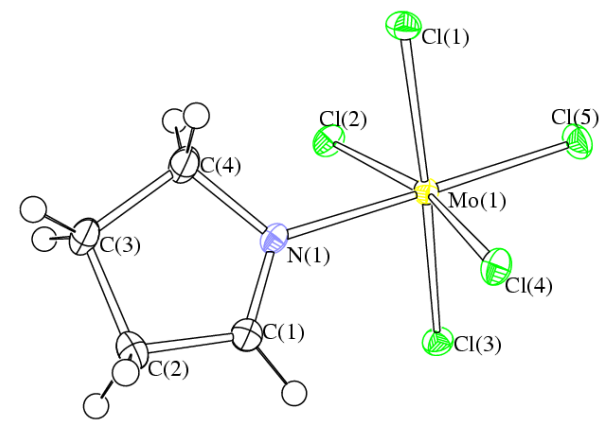

Figure 1. Molecular structure of 1. Displacement ellipsoids are at the 50\% probability level.

Table 1.Selected bond distances $(\AA)$ and angles $\left(^{\circ}\right)$ for $\mathbf{1}$.

\begin{tabular}{llll}
\hline $\mathrm{Mo}(1)-\mathrm{N}(1)$ & $2.193(3)$ & $\mathrm{Mo}(1)-\mathrm{Cl}(1)$ & $2.3252(8)$ \\
$\mathrm{Mo}(1)-\mathrm{Cl}(2)$ & $2.2804(9)$ & $\mathrm{Mo}(1)-\mathrm{Cl}(3)$ & $2.3257(8)$ \\
$\mathrm{Mo}(1)-\mathrm{Cl}(4)$ & $2.2730(10)$ & $\mathrm{Mo}(1)-\mathrm{Cl}(5)$ & $2.2973(9)$ \\
$\mathrm{N}(1)-\mathrm{C}(1)$ & $1.281(4)$ & $\mathrm{N}(1)-\mathrm{C}(4)$ & $1.477(4)$ \\
$\mathrm{C}(1)-\mathrm{C}(2)$ & $1.481(5)$ & $\mathrm{C}(3)-\mathrm{C}(4)$ & $1.526(5)$ \\
$\mathrm{C}(2)-\mathrm{C}(3)$ & $1.541(5)$ & & \\
& & & \\
$\mathrm{Cl}(1)-\mathrm{Mo}(1)-\mathrm{Cl}(3)$ & $176.33(3)$ & $\mathrm{Cl}(2)-\mathrm{Mo}(1)-\mathrm{Cl}(4)$ & $165.07(3)$ \\
$\mathrm{Cl}(5)-\mathrm{Mo}(1)-\mathrm{N}(1)$ & $177.62(7)$ & $\mathrm{Mo}(1)-\mathrm{N}(1)-\mathrm{C}(1)$ & $125.3(2)$ \\
$\mathrm{Mo}(1)-\mathrm{N}(1)-\mathrm{C}(4)$ & $124.8(2)$ & $\mathrm{C}(1)-\mathrm{N}(1)-\mathrm{C}(4)$ & $109.9(3)$ \\
$\mathrm{N}(1)-\mathrm{C}(1)-\mathrm{C}(2)$ & $115.4(3)$ & $\mathrm{C}(1)-\mathrm{C}(2)-\mathrm{C}(3)$ & $102.0(3)$ \\
$\mathrm{C}(2)-\mathrm{C}(3)-\mathrm{C}(4)$ & $104.1(3)$ & $\mathrm{C}(3)-\mathrm{C}(4)-\mathrm{N}(1)$ & $105.4(3)$ \\
\hline
\end{tabular}

Compound 1 represents a very rare example of crystallographically characterized $\mathrm{MoCl}_{5} \mathrm{~L}$ ( $\mathrm{L}=$ organic molecule) complex. ${ }^{18}$ The $\mathrm{Mo}(\mathrm{V})$ centre is octahedrally coordinated to five chlorides and one pyrroline (3,4-dihydro-2H-pyrrole) ligand. Pyrroline is a valuable compound ${ }^{19}$ which has been produced from pyrrolidine by means of various oxidants. ${ }^{20}$

A limited number of metal complexes containing pyrroline are known and in all of them the pyrroline ligand is bonded through the $\mathrm{N}$-atom, ${ }^{21}$ apart one case in which pyrroline is $\eta^{2}$ coordinated via the imine bond. ${ }^{22}$ The Mo(1)-N(1) distance [2.193(3) $\AA$ ] is typical of a $\mathrm{N}\left(\mathrm{sp}^{2}\right)-\mathrm{Mo}(\mathrm{V})$ dative bond, ${ }^{23}$ while $\mathrm{C}(1)-\mathrm{N}(1)[1.281(4) \AA]$ is an imine double bond. ${ }^{21,22,24}$

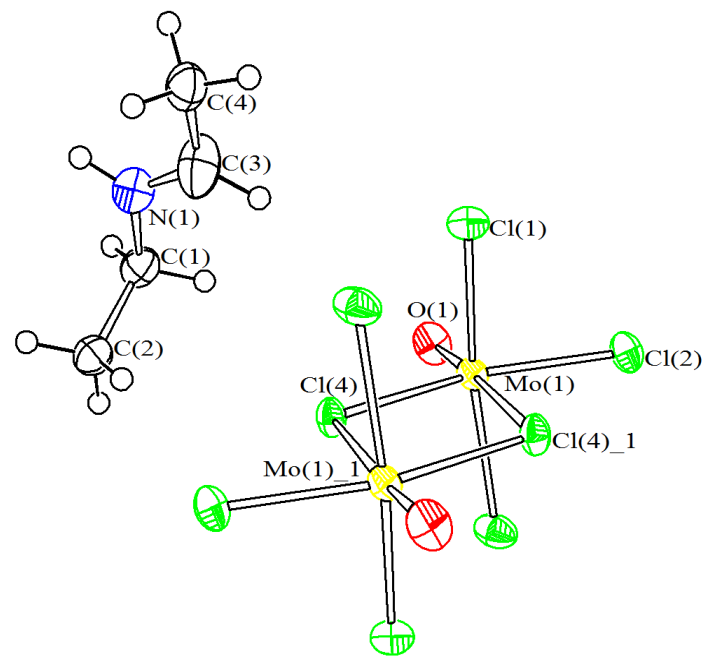

Figure 2. Molecular structure of 2. Displacement ellipsoids are at the 50\% probability level. Symmetry transformations used to generate equivalent atoms: $-\mathrm{x},-\mathrm{y}+1,-\mathrm{z}+1$.

Table 2. Selected bond distances $(\AA)$ and angles $\left(^{\circ}\right)$ for 2

\begin{tabular}{llll}
\hline $\mathrm{Mo}(1)-\mathrm{O}(1)$ & $1.648(2)$ & $\mathrm{Mo}(1)-\mathrm{Cl}(1)$ & $2.3718(10)$ \\
$\mathrm{Mo}(1)-\mathrm{Cl}(2)$ & $2.3380(10)$ & $\mathrm{Mo}(1)-\mathrm{Cl}(3)$ & $2.3650(10)$ \\
$\mathrm{Mo}(1)-\mathrm{Cl}(4)$ & $2.4055(9)$ & $\mathrm{Mo}(1)-\mathrm{Cl}\left(4 \_1\right)$ & $2.865(2)$ \\
$\mathrm{N}(1)-\mathrm{C}(1)$ & $1.472(5)$ & $\mathrm{N}(1)-\mathrm{C}(3)$ & $1.276(5)$
\end{tabular}


$\mathrm{C}(1)-\mathrm{C}(2)$

$1.501(5)$

$\mathrm{C}(3)-\mathrm{C}(4)$

$1.467(6)$

$\mathrm{Cl}(1)-\mathrm{Mo}(1)-\mathrm{Cl}(3) \quad 163.47(3)$

$\mathrm{O}(1)-\mathrm{Mo}(1)-\mathrm{Cl}(4 \quad 1) \quad 175.47(3)$

$\mathrm{O}(1)-\mathrm{Mo}(1)-\mathrm{Cl}(2) \quad 102.66(9)$

$\mathrm{C}(1)-\mathrm{C}(1)-\mathrm{N}(1) \quad 109.8(3)$

$\mathrm{N}(1)-\mathrm{C}(3)-\mathrm{C}(4) \quad 122.3(4)$

$\mathrm{Cl}(2)-\mathrm{Mo}(1)-\mathrm{Cl}(4)$

$157.89(3)$

$\mathrm{Cl}(4)-\mathrm{Mo}(1)-\mathrm{Cl}\left(4 \_1\right) \quad 76.07(3)$

$\operatorname{Mo}(1)-\mathrm{Cl}(4)-\mathrm{Mo}\left(\overline{1}_{-} 1\right) \quad 103.93$

$\mathrm{C}(1)-\mathrm{N}(1)-\mathrm{C}(3)$

125.1(4)

Symmetry transformations used to generate equivalent atoms: $-\mathrm{x},-\mathrm{y}+1,-\mathrm{z}+1$

Compound $\mathbf{2}$ is an ionic one, composed of $[\mathrm{MeCH}=\mathrm{NHEt}]^{+}$cations and $\left[\mathrm{Mo}_{2} \mathrm{O}_{2} \mathrm{Cl}_{8}\right]^{2-}$ anions. The structure of $[\mathrm{MeCH}=\mathrm{NHEt}]^{+}$is unprecedented, but closely related to the crystallographically characterized cation $\left[\mathrm{Me}_{2} \mathrm{C}=\mathrm{N}(\mathrm{H})(\mathrm{Et})\right]^{+} .{ }^{25}$ The iminium $\mathrm{N}(1)-\mathrm{C}(3)$ interaction [1.276(5) $\AA$ ] displays a typical double bond character. In addition, the $\mathrm{NH}$ iminium group is involved in inter-molecular $\mathrm{H}-$ bonds with the terminal $\mathrm{Cl}$ ligand of the anion $[\mathrm{N}(1)-\mathrm{H}(1) 0.88 \AA$, $\mathrm{H}(1) \cdots \mathrm{Cl}(4) \# 1 \quad 2.92 \quad \AA, \quad \mathrm{N}(1) \cdots \mathrm{Cl}(4) \# 1 \quad 3.770(3) \quad \AA$, $<\mathrm{N}(1) \mathrm{H}(1) \mathrm{Cl}(4) \# 1163.7^{\circ} ; \mathrm{N}(1)-\mathrm{H}(1) 0.88 \AA, \mathrm{H}(1) \cdots \mathrm{Cl}(3) \# 12.99 \AA$, $\mathrm{N}(1) \cdots \mathrm{Cl}(3) \# 1 \quad 3.569(4) \AA \AA \quad<\mathrm{N}(1) \mathrm{H}(1) \mathrm{Cl}(3) \# 1 \quad 125.1^{\circ} ; \mathrm{N}(1)-\mathrm{H}(1)$ $0.88 \AA, \quad \mathrm{H}(1) \cdots \mathrm{Cl}(1) \# 2 \quad 2.92 \AA, \quad \mathrm{N}(1) \cdots \mathrm{Cl}(1) \# 2 \quad 3.423(4) \AA$, $<\mathrm{N}(1) \mathrm{H}(1) \mathrm{Cl}(1) \# 2 \quad 117.7^{\circ}$; symmetry transformations used: \#1 $\mathrm{x}+1 / 2,-\mathrm{y}+1 / 2, \mathrm{z}-1 / 2 ; \# 2-\mathrm{x}+1 / 2, \mathrm{y}-1 / 2,-\mathrm{z}+1 / 2]$

The $\left[\mathrm{Mo}_{2} \mathrm{O}_{2} \mathrm{Cl}_{8}\right]^{2-}$ anion is located on an inversion centre and displays a dimeric structure, approximately consisting of two edgesharing octahedra, as previously found in related salts. ${ }^{26}$ The $\mathrm{Mo}(1)-\mathrm{O}(1)$ bond [1.648(2) $\AA$ ] reveals a strong $\pi$-character, as expected for a $\mathrm{Mo}(\mathrm{V})=\mathrm{O}$ unit. ${ }^{33 \mathrm{a}-\mathrm{c}, 26}$ The chloride bridges are very asymmetric, being $\mathrm{Mo}(1)-\mathrm{Cl}(4)[2.4055(9) \AA]$, trans to $\mathrm{Cl}(2)$, considerably shorter than $\mathrm{Mo}(1)-\mathrm{Cl}(4) \_1[2.865(2) \AA]$, trans to the stronger oxido ligand.

The magnetic analyses of $\mathbf{1}$ and $\mathbf{2}$ were indicative of $\mathrm{Mo}(\mathrm{V})$ chloride derivatives. ${ }^{33}$ In the IR spectrum of $\mathbf{1}$, diagnostic absorption for the imine group has been detected at $1572 \mathrm{~cm}^{-1}$. The IR spectrum of 2 displays the absorptions related to the $[\mathrm{C}=\mathrm{N}]$ and $[\mathrm{Mo}=\mathrm{O}]{ }^{33}$ moieties at ca. 1700 and at $989 \mathrm{~cm}^{-1}$, respectively.

The oxidative dehydrogenation of secondary amines to imines is a known process ${ }^{27}$ with implications in the hydrogen storage issue, ${ }^{28}$ nevertheless this reaction is unusual in the landscape of the chemistry of metal chlorides. ${ }^{29}$ In the present case, it is presumable that the $\mathrm{Mo}(\mathrm{V})$ centre exerts its oxidant power ${ }^{30}$ towards the amine reactants, even though $\mathrm{GC}$ analyses on $\mathrm{MoCl}_{5} /$ diethylamine and $\mathrm{MoCl}_{5} /$ pyrrolidine mixtures evidenced the release of very low amounts of $\mathrm{H}_{2}$ as possible reduction product. As a matter of fact, magnetic analysis on the pyrrolidine $/ \mathrm{MoCl}_{5}$ reaction residue suggested the presence of a mixture of $\mathrm{Mo}(\mathrm{V})$ and $\mathrm{Mo}(\mathrm{IV})$ species $(\mu$ $=1.91 \mathrm{BM})$. The formation of Mo(IV) by-products is in agreement with the computed thermodynamic variation for the reaction reported in Eqn. $1, \Delta \mathrm{G}=-72.3 \mathrm{kcal} \mathrm{mol}^{-1}$. Mo(IV) chloride was modelled on the basis of the hexameric structure reported in the literature. ${ }^{31}$

$1.5 \mathrm{Mo}_{2} \mathrm{Cl}_{10}+\mathrm{NH}\left(\mathrm{CH}_{2}\right)_{4} \rightarrow\left[\mathrm{MoCl}_{5}\left\{\mathrm{NCH}\left(\mathrm{CH}_{2}\right)_{3}\right\}\right]+2 \mathrm{HCl}+1 / 3 \mathrm{Mo}_{6} \mathrm{Cl}_{24}$

\section{Reactions of $\mathrm{MoCl}_{5}$ with $\mathrm{N}$-(trimethylsilyl)dialkylamines.}

With the idea in mind to access $\mathrm{Mo}(\mathrm{V})$ chloride amide compounds, we moved to study the reactions of $\mathrm{MoCl}_{5}$ with variable amounts of $N$-(trimethylsilyl)dialkylamines, these being expected to act as clean $\mathrm{Cl} / \mathrm{NR}_{2}$ exchangers. ${ }^{5,32}$ Indeed the $1: 1$ molar reaction of $\mathrm{MoCl}_{5}$ with $\mathrm{Et}_{2} \mathrm{NSiMe}_{3}$ in dichloromethane afforded the chloride amide compound $\left[\mathrm{MoCl}_{4}\left(\mathrm{NEt}_{2}\right)\right], 3$, which was isolated in $65 \%$ yield after work up (Eqn. 2).

$\mathrm{MoCl}_{5}+\mathrm{Et}_{2} \mathrm{NSiMe}_{3} \rightarrow\left[\mathrm{MoCl}_{4}\left(\mathrm{NEt}_{2}\right)\right]+\mathrm{Me}_{3} \mathrm{SiCl}$

$$
3
$$

The synthesis of 3 originates from the selective $\mathrm{Cl} / \mathrm{NEt}_{2}$ exchange between the reactants. The use of two/three equivalents of $\mathrm{Et}_{2} \mathrm{NSiMe}_{3}$ resulted in the formation of mixtures of products. Compound $\mathbf{3}$ was characterized by elemental analysis, magnetic analysis and IR spectroscopy. On account of the fact that crystallographic characterizations of $\mathrm{Mo}(\mathrm{V})$ chloride amide complexes are still absent in the literature, we made several attempts in order to obtain X-ray quality crystals of $\mathbf{3}$. Unfortunately, these attempts were not successful. In the absence of X-ray data, we performed DFT calculations aimed to the prediction of the most stable structure. A range of possibilities were considered (see Figure S2, structures 3A-3C); the mononuclear structure (3-mono) and the dinuclear one with the amido groups in relative trans-equatorial position (3A) resulted the most stable ones, exhibiting strictly comparable relative Gibbs energies (Figures 3a, 3b). It should be noted that the crystallographically characterized complex $\left[\mathrm{NbCl}_{4}\left(\mathrm{NEt}_{2}\right)\right]$ displays a dinuclear structure matching that of $\mathbf{3} \mathbf{A}^{3 \mathrm{a}}$ DFT calculations ruled out the possibility of Mo-Mo covalent interaction in $\mathbf{3 A}$, being the triplet state more stable than the corresponding singlet one by about $11 \mathrm{kcal} \mathrm{mol}^{-1}$. This is in agreement with the magnetic measurement performed on $\mathbf{3}$ ( $\mu=1.44$ $\mathrm{BM})$, indicating the presence of isolated $\mathrm{Mo}(\mathrm{V})$ centers. $^{33}$

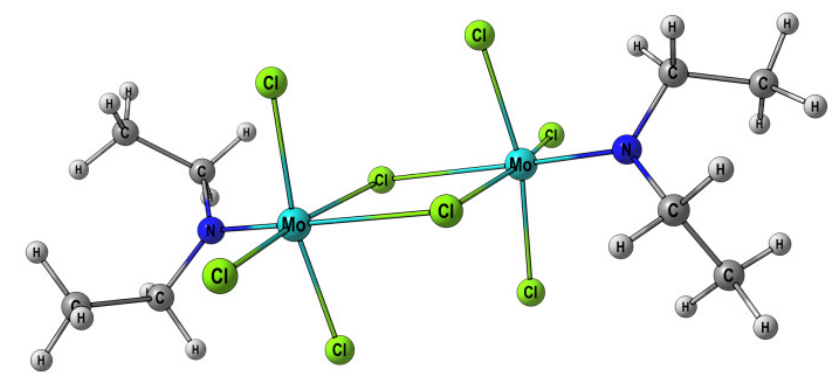

Figure 3a. DFT-optimized geometry of 3A, C-PCM/-B97X calculations Selected computed bond lengths $(\AA)$ : Mo-N 1.878, 1.885; Mo-Cl (terminal) 2.295, 2.296, 2.316, 2.324, 2.325, 2.326; Mo-Cl (bridging) 2.504, 2.514, 2.713, 2.719; Mo $\cdots$ Mo 4.016. Selected computed angles (deg):N-Mo$\mathrm{Cl}$ (terminal) 97.1， 100.5，92.3，92.8，93.1，94.6; $\mathrm{Cl}$ (bridging)-Mo$\mathrm{Cl}$ (bridging) 79.5, 79.8; Mo-Cl(bridging)-Mo 100.3, 100.4.

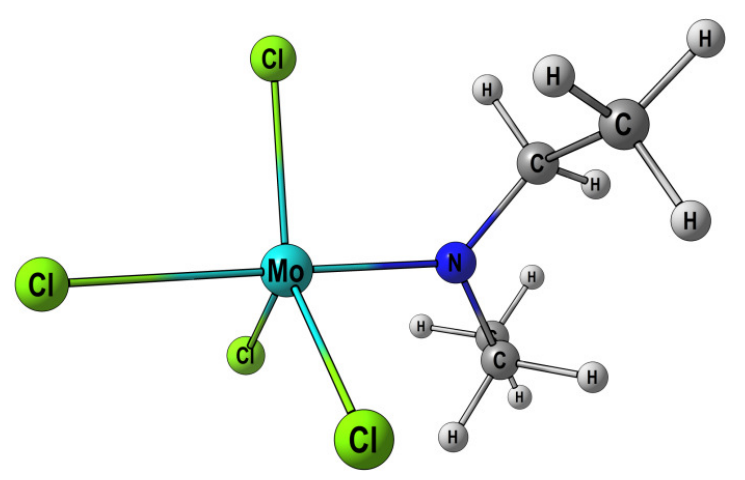

Figure 3b. DFT-optimized geometry of 3-mono, C-PCM/-B97X calculations. Selected computed bond lengths $(\AA)$ : Mo-N 2.022; Mo$\mathrm{Cl}$ (apical) 2.389; Mo-Cl(equatorial) 2.263, 2.287, 2.308. Selected computed angles (deg): $\mathrm{N}-\mathrm{Mo}-\mathrm{Cl}$ (apical) 176.4; $\mathrm{N}-\mathrm{Mo}-\mathrm{Cl}$ (equatorial) 87.5, 90.1, 91.2.

The reaction of $\mathrm{MoCl}_{5}$ with one equivalent of $\mathrm{Me}_{2} \mathrm{NSiMe}_{3}$ in dichloromethane led to a mixture of metal compounds presumably containing a prevalence of $\mathrm{Mo}(\mathrm{V})$ centres $(\mu=1.33 \mathrm{BM}){ }^{33} \mathrm{~A}$ crystallization procedure furnished few X-ray quality crystals (4). These crystals consist of a 1:1 mixture of the Mo(IV) complex $\left[\mathrm{MoCl}_{3}\left(\mathrm{NMe}_{2}\right)\left(\kappa^{2}-\mathrm{Me}_{2} \mathrm{NCH}_{2} \mathrm{NMe}_{2}\right)\right], 4 \mathbf{4}$, and the $\mathrm{Mo}(\mathrm{V})$ complex $\left[\mathrm{MoCl}_{3}(\mathrm{NMe})\left(\kappa^{2}-\mathrm{Me}_{2} \mathrm{NCH}_{2} \mathrm{NMe}_{2}\right)\right]$, 4b. The two structures are shown in Figure 4, while relevant bonding parameters are reported in Table 3. In both $\mathbf{4 a - b}$, the Mo centres display a distorted octahedral geometry, being bonded to three chlorides in mer position, a chelating $\kappa^{2}-\mathrm{Me}_{2} \mathrm{NCH}_{2} \mathrm{NMe}_{2}$ ligand and an imido [NMe] (4a) or [amido] $\mathrm{NMe}_{2}$ (4b) ligand. As far as we are aware, $4 \mathbf{a}-\mathbf{b}$ represent 
the first cases of structurally characterized Mo-complexes with the $\mathrm{Me}_{2} \mathrm{NCH}_{2} \mathrm{NMe}_{2}$ ligand, and only a few examples of $\mathrm{Co}, \mathrm{Ni}, \mathrm{Fe}$ and $\mathrm{Re}$ complexes with the same ligand have been found within the Cambridge Crystallographic Data Centre. ${ }^{34}$ The $\operatorname{Mo}(1)-\mathrm{N}(1)$ $\left[\begin{array}{ll}2.332(5) & \AA\end{array}\right]$ and $\operatorname{Mo}(1)-\mathrm{N}(2)[2.255(3) \AA]$ contacts of 2a are considerably longer than $\mathrm{Mo}(1)-\mathrm{N}(3)$ [1.911(5) $\AA$ ], in view of the amido nature of the latter group. ${ }^{35} \mathrm{~A}$ further decrease in the related $\mathrm{Mo}(2)-\mathrm{N}(6)$ distance $[1.746(5) \AA]$ is observed in the imido complex $\mathbf{2 b}$, in keeping with previous findings. ${ }^{36}$
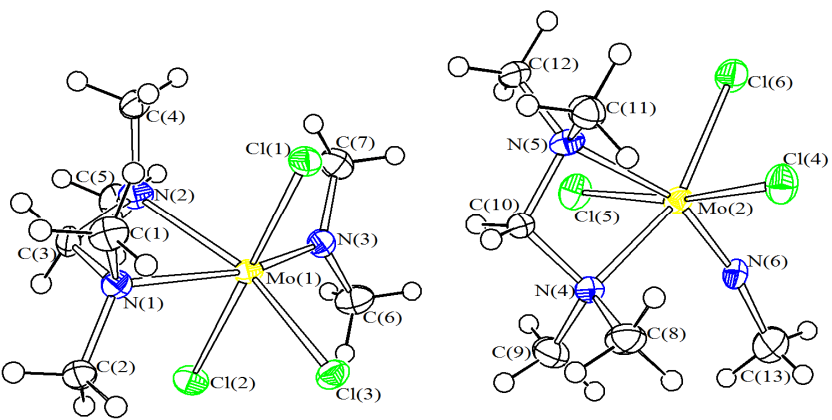

Figure 4. Molecular structure of 4. Displacement ellipsoids are at the 50\% probability level.

Table 3. Selected bond distances $(\AA)$ and angles $\left(^{\circ}\right)$ for 4

\begin{tabular}{llll}
\hline $\mathrm{Mo}(1)-\mathrm{Cl}(1)$ & $2.3954(15)$ & $\mathrm{Mo}(1)-\mathrm{Cl}(2)$ & $2.4289(15)$ \\
$\mathrm{Mo}(1)-\mathrm{Cl}(3)$ & $2.3817(14)$ & $\mathrm{Mo}(1)-\mathrm{N}(1)$ & $2.332(5)$ \\
$\mathrm{Mo}(1)-\mathrm{N}(2)$ & $2.255(5)$ & $\mathrm{Mo}(1)-\mathrm{N}(3)$ & $1.911(5)$ \\
$\mathrm{N}(1)-\mathrm{C}(3)$ & $1.487(7)$ & $\mathrm{N}(2)-\mathrm{C}(3)$ & $1.500(7)$ \\
$\mathrm{C}(6)-\mathrm{N}(3)$ & $1.484(8)$ & $\mathrm{C}(7)-\mathrm{N}(3)$ & $1.465(8)$ \\
$\mathrm{Mo}(2)-\mathrm{Cl}(4)$ & $2.3941(16)$ & $\mathrm{Mo}(2)-\mathrm{Cl}(5)$ & $2.4102(16)$ \\
$\mathrm{Mo}(2)-\mathrm{Cl}(6)$ & $2.3790(16)$ & $\mathrm{Mo}(2)-\mathrm{N}(4)$ & $2.235(5)$ \\
$\mathrm{Mo}(2)-\mathrm{N}(5)$ & $2.402(5)$ & $\mathrm{Mo}(2)-\mathrm{N}(6)$ & $1.746(5)$ \\
$\mathrm{N}(4)-\mathrm{C}(10)$ & $1.496(7)$ & $\mathrm{N}(5)-\mathrm{C}(10)$ & $1.481(7)$ \\
$\mathrm{C}(13)-\mathrm{N}(6)$ & $1.409(9)$ & & \\
& & & \\
$\mathrm{Cl}(1)-\mathrm{Mo}(1)-\mathrm{Cl}(2)$ & $175.26(5)$ & $\mathrm{Cl}(3)-\mathrm{Mo}(1)-\mathrm{N}(2)$ & $158.21(13)$ \\
$\mathrm{N}(1)-\mathrm{Mo}(1)-\mathrm{N}(3)$ & $160.62(18)$ & $\mathrm{N}(1)-\mathrm{Mo}(1)-\mathrm{N}(2)$ & $62.85(16)$ \\
$\mathrm{Mo}(1)-\mathrm{N}(3)-\mathrm{C}(6)$ & $124.9(4)$ & $\mathrm{Mo}(1)-\mathrm{N}(3)-\mathrm{C}(7)$ & $124.5(4)$ \\
$\mathrm{C}(6)-\mathrm{N}(3)-\mathrm{C}(7)$ & $109.9(5)$ & $\mathrm{Cl}(6)-\mathrm{Mo}(2)-\mathrm{N}(4)$ & $159.51(13)$ \\
$\mathrm{Cl}(4)-\mathrm{Mo}(2)-\mathrm{Cl}(5)$ & $169.13(6)$ & $\mathrm{N}(4)-\mathrm{Mo}(2)-\mathrm{N}(5)$ & $61.62(17)$ \\
$\mathrm{N}(5)-\mathrm{Mo}(2)-\mathrm{N}(6)$ & $156.9(2)$ & $\mathrm{Mo}(2)-\mathrm{N}(6)-\mathrm{C}(13)$ & $166.3(5)$ \\
\hline
\end{tabular}

The presence of $\mathrm{Me}_{2} \mathrm{NCH}_{2} \mathrm{NMe}_{2}$ in $\mathbf{4 a}, \mathbf{b}$ is the result of the involvement of the solvent $\left(\mathrm{CH}_{2} \mathrm{Cl}_{2}\right)$ in the $\mathrm{Cl} / \mathrm{NMe}_{2}$ exchange. ${ }^{37}$ Accordingly, significant amounts of $\mathrm{Me}_{2} \mathrm{~N}\left(\mathrm{CH}_{2}\right)_{2} \mathrm{NMe}_{2}$ were recovered after hydrolysis of the $\mathrm{MoCl}_{5} / \mathrm{Me}_{2} \mathrm{NSiMe}_{3}$ mixture in 1,2dichloroethane. ${ }^{376}$ Neither $\mathrm{Me}_{2} \mathrm{NCH}_{2} \mathrm{NMe}_{2}$ nor $\mathrm{Me}_{2} \mathrm{~N}\left(\mathrm{CH}_{2}\right)_{2} \mathrm{NMe}_{2}$ were recognized from the reaction of $\mathrm{MoCl}_{5}$ with $\mathrm{Me}_{2} \mathrm{NSiMe}_{3}$ in heptane, although even in this case unambiguous characterization of the metal products failed.

\section{Reactions of $\mathrm{MoCl}_{5}$ with primary amines.}

The 1:1 reactions of $\mathrm{MoCl}_{5}$ with $\mathrm{NH}_{2} \mathrm{R}\left(\mathrm{R}=\mathrm{Cy},{ }^{\mathrm{t}} \mathrm{Bu},{ }^{\mathrm{i}} \mathrm{Pr}, 2\right.$,6$\mathrm{C}_{6} \mathrm{H}_{3} \mathrm{Me}_{2}, \mathrm{CH}_{2} \mathrm{Ph}$ ) were studied. These reactions afforded, after elimination of the volatile materials, paramagnetic solid mixtures. After hydrolytic treatment of the latter, the starting amines were identified (NMR) as largely prevalent components in the respective organic phases. Only traces of $\mathrm{NH}_{2}=\mathrm{CHPh}$ were recognized from $\mathrm{MoCl}_{5} / \mathrm{NH}_{2} \mathrm{CH}_{2} \mathrm{Ph}$. These results indicate that primary amines are generally not prone to oxidation by molybdenum pentachloride, in contrast to what seen for secondary amines. Numerous attempts were performed with the aim of isolating clean metal products from $\mathrm{MoCl}_{5} / \mathrm{NH}_{2} \mathrm{R}$. These attempts were successful in two cases, thus the $\mathrm{Mo}(\mathrm{VI})$ imido chloride complexes $\left[\mathrm{MoCl}_{4}(\mathrm{NR})\right]_{2}(\mathrm{R}=\mathrm{Cy}, \mathbf{5 a} ; \mathrm{R}=$ ${ }^{\mathrm{t}} \mathrm{Bu}, \mathbf{5 b}$ ) were isolated in ca. $40 \%$ yields by crystallization procedures from $\mathrm{MoCl}_{5} / \mathrm{NH}_{2} \mathrm{R}\left(\mathrm{R}=\mathrm{Cy},{ }^{\mathrm{t}} \mathrm{Bu}\right)$, Scheme 3 .

$$
\begin{aligned}
& \mathrm{MoCl}_{5} \stackrel{\mathrm{NH}_{2} \mathrm{R}}{\longrightarrow}\left[\mathrm{MoCl}_{3}(\mathrm{NR})(\mu-\mathrm{Cl})\right]_{2} \\
& \mathrm{R}=\mathrm{Cy}, \mathbf{5} \mathbf{a} ;{ }^{t} \mathrm{Bu}, \mathbf{5 b}
\end{aligned}
$$

Scheme 3. Formation of Mo(VI) imido chloride complexes from the reactions of $\mathrm{MoCl}_{5}$ with primary amines.

Compound $\mathbf{5 b}$ was previously obtained in modest yield by $\mathrm{Cl}_{2}$ oxidation of a $\mathrm{Mo}(\mathrm{V})$ imido precursor. ${ }^{38}$ Here, it was identified by elemental analysis and single crystal X-ray analysis. The novel 5a was characterized by IR and NMR spectroscopy, and the structure was elucidated by a single crystal X-ray diffraction study. 5a is diamagnetic, and displays an intense IR band at $1239 \mathrm{~cm}^{-1}$, accounting for the $[\mathrm{Mo}=\mathrm{N}]$ moiety. The ORTEP molecular structure of 5a is shown in Figure 5, while relevant bonding parameters are reported in Table 4.

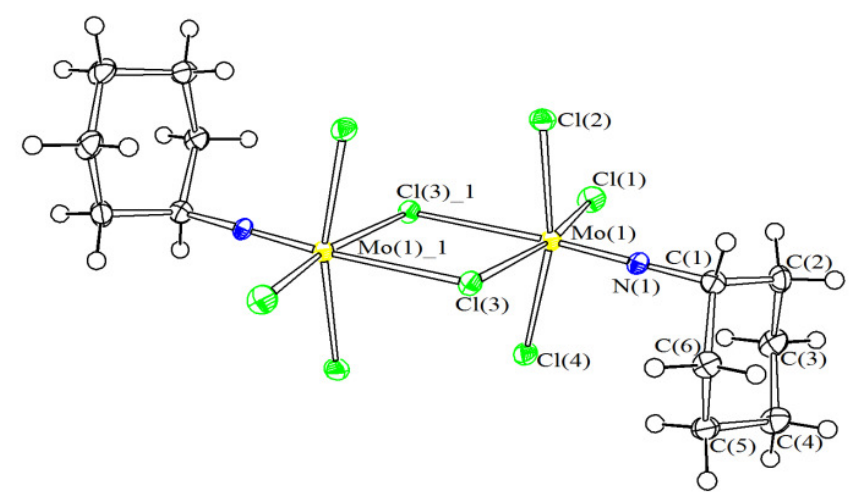

Figure 5. Molecular structure of 5a. Displacement ellipsoids are at the 50\% probability level. Symmetry transformations used to generate equivalent atoms: $-\mathrm{x}+1,-\mathrm{y}+2,-\mathrm{z}+2$.

Table 4.Selected bond distances $(\AA)$ and angles $\left(^{\circ}\right)$ for $\mathbf{5 a}$.

\begin{tabular}{llll}
\hline $\mathrm{Mo}(1)-\mathrm{Cl}(1)$ & $2.2966(10)$ & $\mathrm{Mo}(1)-\mathrm{Cl}(2)$ & $2.2996(10)$ \\
$\mathrm{Mo}(1)-\mathrm{Cl}(3))$ & $2.4562(10)$ & $\mathrm{Mo}(1)-\mathrm{Cl}\left(3 \_1\right)$ & $2.6996(11)$ \\
$\mathrm{Mo}(1)-\mathrm{Cl}(4)$ & $2.3194(9)$ & $\mathrm{Mo}(1)-\mathrm{N}(1)$ & $1.689(3)$ \\
$\mathrm{N}(1)-\mathrm{C}(1)$ & $1.444(4)$ & $\mathrm{C}(1)-\mathrm{C}(2)$ & $1.543(5)$ \\
$\mathrm{C}(2)-\mathrm{C}(3)$ & $1.517(5)$ & $\mathrm{C}(3)-\mathrm{C}(4)$ & $1.540(5)$ \\
$\mathrm{C}(4)-\mathrm{C}(5)$ & $1.524(5)$ & $\mathrm{C}(5)-\mathrm{C}(6)$ & $1.522(5)$ \\
$\mathrm{C}(6)-\mathrm{C}(1)$ & $1.546(5)$ & & \\
& & & $165.62(3)$ \\
$\mathrm{Cl}(1)-\mathrm{Mo}(1)-\mathrm{Cl}(3)$ & $166.62(3)$ & $\mathrm{Cl}(2)-\mathrm{Mo}(1)-\mathrm{Cl}(4)$ & $79.03(3)$ \\
$\mathrm{N}(1)-\mathrm{Mo}(1)-\mathrm{Cl}(3-1)$ & $172.23(9)$ & $\mathrm{Cl}(3)-\mathrm{Mo}(1)-\mathrm{Cl}\left(3 \_1\right)$ & $100.97(3)$ \\
$\mathrm{Mo}(1)-\mathrm{N}(1)-\mathrm{C}(1)$ & $175.3(2)$ & $\mathrm{Mo}(1)-\mathrm{Cl}(3)-\mathrm{Mo}\left(1 \_1\right)$ & 10.9 \\
\hline
\end{tabular}

Symmetry transformations used to generate equivalent atoms: $-\mathrm{x}+1,-\mathrm{y}+2$, $-\mathrm{z}+2$

The structure of $\mathbf{5 a}$ is closely related to that previously reported for $\mathbf{5 b},{ }^{38}$ showing an almost identical geometry and bonding parameters. In 5a, the Mo(VI) centres display a distorted octahedral geometry, being bonded to one imido, three terminal and two edge bridging $\mathrm{Cl}$ ligands. The $\mathrm{Mo}(1)-\mathrm{N}(1)$ contact $[1.689(3) \AA]$ is rather short, as expected for a $\mathrm{Mo}(\mathrm{VI})-\mathrm{N}$ multiple bond, and has a strong trans influence. Thus, $\mathrm{Mo}(1)-\mathrm{Cl}(3) \_1$ [2.6996(11) $\left.\AA\right]$ is considerably elongated compared to $\mathrm{Mo}(1)-\mathrm{Cl}(3)$ [2.4562(10) $\AA]$, which is trans to a terminal chloride, and $\mathrm{Mo}(1)-\mathrm{N}(1)-\mathrm{C}(1)\left[175.3(2)^{\circ}\right]$ is almost linear. The molecule is located on an inversion centre and, hence, only half of it is present within the asymmetric unit of the unit cell. The synthesis of the Mo(VI) based imido complexes $\mathbf{5 a}, \mathbf{b}$ represents a very unusual result in the context of the chemistry of metal halides with aliphatic amines. Indeed imido ligands have been typically introduced in metal complexes via deprotonation of amines or amides (see Introduction). ${ }^{39}$ This synthetic strategy does not imply any change in the oxidation state of the metal centre, unless specific oxidative co-reactants are involved. ${ }^{40}$ Imido ligands have been generated also by metathesis of metal oxide chlorides with isocyanates ${ }^{41}$ and by addition of azides, $\mathrm{RN}_{3}$, to metal complexes. 
The latter approach has been successfully employed for the synthesis of $\left[\mathrm{Mo}^{(\mathrm{VI})} \mathrm{Cl}_{4}(\mathrm{NR})(\right.$ thf $\left.)\right]$ from $\left[\mathrm{Mo}^{(\mathrm{IV})} \mathrm{Cl}_{4}(\mathrm{thf})_{2}\right],{ }^{42}$ the oxidation of the metal centre being permitted by $\mathrm{N}_{2}$ release.

DFT calculations were performed on the $\mathrm{MoCl}_{5} / \mathrm{NH}_{2} \mathrm{Cy}$ system, in order to supply a plausible reaction pathway. The formation of $\left[\mathrm{MoCl}_{4}(\mathrm{NCy})\right]_{2}$ is probably preceded by that of the intermediate $\mathrm{Mo}(\mathrm{V})$ dimeric complex $\left[\mathrm{MoCl}_{4}(\mathrm{NHCy})\right]_{2}$ (Figure 6), from $\mathrm{Mo}_{2} \mathrm{Cl}_{10}$ and $\mathrm{NH}_{2} \mathrm{Cy}$ by $\mathrm{HCl}$ elimination $\left(\Delta \mathrm{G}=-43.9 \mathrm{kcal} \mathrm{mol}^{-1}\right)$.

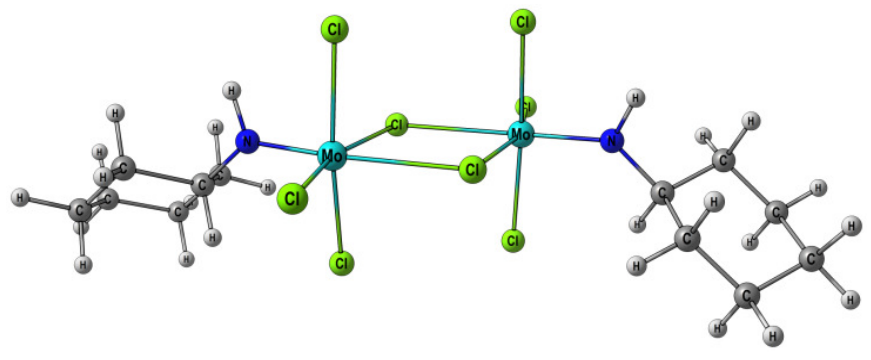

Figure 6. DFT-optimized geometry of $\left[\mathrm{MoCl}_{4}(\mathrm{NHCy})\right]_{2}, \mathrm{C}-\mathrm{PCM} /-\mathrm{B} 97 \mathrm{X}$ calculations. Selected computed bond lengths $(\AA)$ : Mo-N 1.853, 1.853; $\mathrm{Mo}-\mathrm{Cl}$ (terminal) 2.275, 2.275, 2.318, 2.318, 2.325, 2.325; Mo-Cl (bridging) 2.499, 2.499, 2.695, 2.695; Mo---Mo 4.030; N-H 1.029, 1.029. Selected computed angles (deg): $\mathrm{N}-\mathrm{Mo}-\mathrm{Cl}($ terminal) $101.4, \quad 101.4, \quad 88.4, \quad 88.4, \quad 92.3,92.3$; $\mathrm{Cl}$ (bridging)-Mo-Cl(bridging) 78.3, 78.3; Mo-Cl(bridging)-Mo 101.7, 101.7.

A possible pathway going from $\left[\mathrm{MoCl}_{4}(\mathrm{NHCy})\right]_{2}$ to $\left[\mathrm{MoCl}_{4}(\mathrm{NCy})\right]_{2}$ could involve, in principle, the formation of $\mathrm{H}_{2}$ as a by-product (Eqn. 3 ). This reaction should be slightly thermodynamically unfavourable $\left(\Delta \mathrm{G}=\right.$ ca. $\left.0.9 \mathrm{kcal} \mathrm{mol}^{-1}\right)$ and, accordingly, $\mathrm{GC}$ analyses on $\mathrm{MoCl}_{5} /$ diethylamine and $\mathrm{MoCl}_{5} /$ pyrrolidine mixtures pointed out the formation of only minor amounts of $\mathrm{H}_{2}$. It has to be observed that the $\mathrm{H}_{2}$ dissociation from primary amines is not a common feature, being achieved only by powerful oxidative systems. ${ }^{43}$

$\left[\mathrm{MoCl}_{4}(\mathrm{NHCy})\right]_{2} \rightarrow\left[\mathrm{MoCl}_{4}(\mathrm{NCy})\right]_{2}+\mathrm{H}_{2}$

According to the calculations, a more plausible route from $\left[\mathrm{Mo}^{(\mathrm{V})} \mathrm{Cl}_{4}(\mathrm{NHCy})\right]_{2}$ to $\left[\mathrm{Mo}^{(\mathrm{VI})} \mathrm{Cl}_{4}(\mathrm{NCy})\right]_{2}$ involves the disproportion of the $\mathrm{Mo}(\mathrm{V})$ reactant to $\mathrm{Mo}(\mathrm{VI})$ and $\mathrm{Mo}(\mathrm{IV})$, Eqn. 4. This hypothesis is supported by the calculated $\Delta \mathrm{G}=-8.7 \mathrm{kcal} \mathrm{mol}^{-1}$, and by the fact that magnetic analyses on the reaction residues were in alignment with the presence of mixtures of $\mathrm{Mo}(\mathrm{VI})$ and $\mathrm{Mo}(\mathrm{IV})$ species.

$2\left[\mathrm{MoCl}_{4}(\mathrm{NHCy})\right]_{2} \rightarrow\left[\mathrm{MoCl}_{4}(\mathrm{NCy})\right]_{2}+2 \mathrm{NH}_{2} \mathrm{Cy}+\frac{1}{3} \mathrm{Mo}_{6} \mathrm{Cl}_{24}{ }^{31}$

\section{Reactions of $\mathrm{MoCl}_{5}$ with trialkylamines.}

The 1:1 molar reaction of $\mathrm{MoCl}_{5}$ with tribenzylamine afforded a precipitate whose $\mathrm{Cl}$ and magnetic analysis suggested the prevalent formation of a $\mathrm{Mo}(\mathrm{V})$ compound, presumably $\left[\mathrm{MoCl}_{5}\left\{\mathrm{~N}\left(\mathrm{CH}_{2} \mathrm{Ph}\right)_{3}\right\}\right]$, in admixture with $\mathrm{Mo}(\mathrm{IV})$ containing side products (Scheme 4). A crystallization procedure allowed to isolate the iminium salt $\left[\left(\mathrm{CH}_{2} \mathrm{Ph}\right)_{2} \mathrm{~N}=\mathrm{CHPh}\right]_{2}\left[\mathrm{MoCl}_{6}\right] \cdot \mathrm{CH}_{2} \mathrm{Cl}_{2}, \mathbf{6}$, containing $\mathrm{Mo}(\mathrm{IV})$ anions, that was X-ray characterized (Figure 7, Table 5).

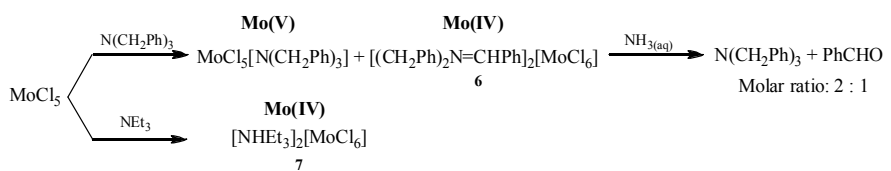

Scheme 4. Reactions of $\mathrm{MoCl}_{5}$ with trialkylamines.

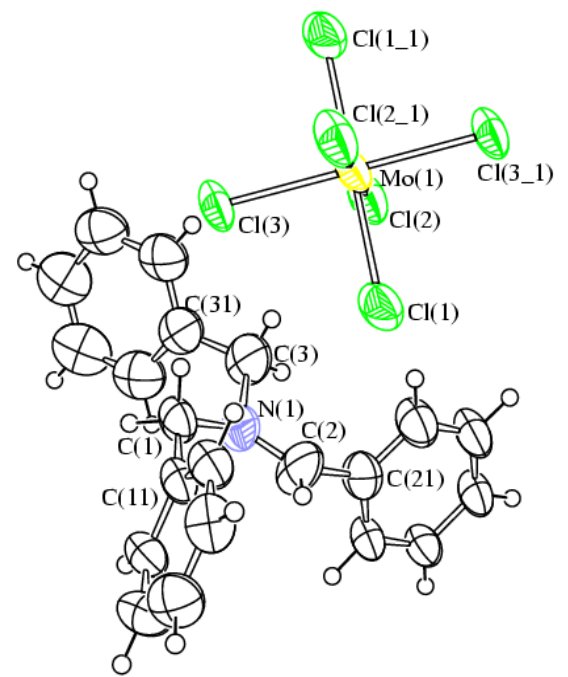

Figure 7. Molecular structure of $\left[\left(\mathrm{CH}_{2} \mathrm{Ph}\right)_{2} \mathrm{~N}=\mathrm{CHPh}\right]_{2}\left[\mathrm{MoCl}_{6}\right]$, 6, with key atoms labeled. Displacement ellipsoids are at the $50 \%$ probability level. Symmetry transformation used to generate equivalent atoms: $-x+2,-y+1,-$ $\mathrm{z}+1$.

Table 5. Selected bond distances $(\AA)$ and angles $\left(^{\circ}\right)$ for $\mathbf{6}$.

\begin{tabular}{llll}
\hline $\mathrm{Mo}(1)-\mathrm{Cl}(1)$ & $2.365(2)$ & $\mathrm{Mo}(1)-\mathrm{Cl}(2)$ & $2.362(2)$ \\
$\mathrm{Mo}(1)-\mathrm{Cl}(3)$ & $2.4169(17)$ & $\mathrm{N}(1)-\mathrm{C}(1)$ & $1.496(10)$ \\
$\mathrm{N}(1)-\mathrm{C}(2)$ & $1.306(11)$ & $\mathrm{N}(1)-\mathrm{C}(3)$ & $1.504(11)$ \\
$\mathrm{C}(1)-\mathrm{C}(11)$ & $1.487(11)$ & $\mathrm{C}(2)-\mathrm{C}(21)$ & $1.473(12)$ \\
$\mathrm{C}(3)-\mathrm{C}(31)$ & $1.486(13)$ & & \\
& & & \\
$\mathrm{C}(1)-\mathrm{N}(1)-\mathrm{C}(2)$ & $121.6(8)$ & $\mathrm{C}(1)-\mathrm{N}(1)-\mathrm{C}(3)$ & $111.6(7)$ \\
$\mathrm{C}(2)-\mathrm{N}(1)-\mathrm{C}(3)$ & $117.9(7)$ & $\mathrm{N}(1)-\mathrm{C}(1)-\mathrm{C}(11)$ & $113.5(7)$ \\
$\mathrm{N}(1)-\mathrm{C}(2)-\mathrm{C}(21)$ & $125.3(9)$ & $\mathrm{N}(1)-\mathrm{C}(3)-\mathrm{C}(31)$ & $115.8(8)$ \\
\hline
\end{tabular}

The conversion of tribenzylamine into the relevant iminium cation was previously realized by $\mathrm{WCl}_{6}$-directed $\mathrm{C}-\mathrm{H}$ activation, initiated by amine to metal single electron transfer, and finally affording the salts $\left[\left(\mathrm{CH}_{2} \mathrm{Ph}\right)_{2} \mathrm{~N}=\mathrm{CHPh}\right]\left[\mathrm{WCl}_{6}\right]$ and $\left[\mathrm{NH}\left(\mathrm{CH}_{2} \mathrm{Ph}\right)_{3}\right]\left[\mathrm{WCl}_{6}\right] .{ }^{1 \mathrm{~b}}$ The formation of $\mathbf{6}$ probably follows a similar pathway, and evidence for the presence of the ammonium $\left[\mathrm{NH}\left(\mathrm{CH}_{2} \mathrm{Ph}\right)_{3}\right]^{+}$in the $\mathrm{MoCl}_{5} / \mathrm{N}\left(\mathrm{CH}_{2} \mathrm{Ph}\right)_{3}$ mixture was supplied by an IR absorption at 1595 $\mathrm{cm}^{-1}{ }^{11 \mathrm{~b}}$ According to NMR analysis on the hydrolyzed reaction mixture, $c a$. one third of the amine reactant was converted into the iminium upon interaction with $\mathrm{MoCl}_{5}$, the iminium being detected as benzaldehyde $\mathrm{PhCHO}$ after hydrolysis.

The 1:1 molar reaction of $\mathrm{MoCl}_{5}$ with $\mathrm{NEt}_{3}$ proceeded with prevalent $\mathrm{Mo}(\mathrm{V})$ to $\mathrm{Mo}(\mathrm{IV})$ reduction (Scheme 4), and a crystallization procedure allowed to isolate some crystals of the Mo(IV) salt $\left[\mathrm{NHEt}_{3}\right]_{2}\left[\mathrm{Mo}_{2} \mathrm{Cl}_{10}\right], 7$ (Figure 8, Tables 6-7). ${ }^{44}$ Actually, crystals of 7 contain a mixture of the $\mathrm{Mo}(\mathrm{IV})$ anion $\left[\mathrm{Mo}_{2} \mathrm{Cl}_{10}\right]^{2-}(80 \%)$ and the $\mathrm{Mo}(\mathrm{V})$ anion $\left[\mathrm{Mo}_{2}(\mathrm{O})_{2} \mathrm{Cl}_{8}\right]^{2-}(20 \%)$, in agreement with the proposed reaction scheme. Coherently with previous findings, the protonation source affording 7 might be a $\mathrm{C}-\mathrm{H}$ activation process analogous to that suggested above for $\mathrm{MoCl}_{5} / \mathrm{N}_{(}\left(\mathrm{CH}_{2} \mathrm{Ph}\right)_{3} .{ }^{12}$ Indeed the IR spectrum of the reaction residue contained two weak bands at 1680 and $1648 \mathrm{~cm}^{-1}$, possibly ascribable to $[\mathrm{C}=\mathrm{N}]$ containing species. Nevertheless, the possibility that fortuitous hydrolysis contributed to the generation of $\left[\mathrm{NHEt}_{3}\right]^{+}$must not be ruled out. 

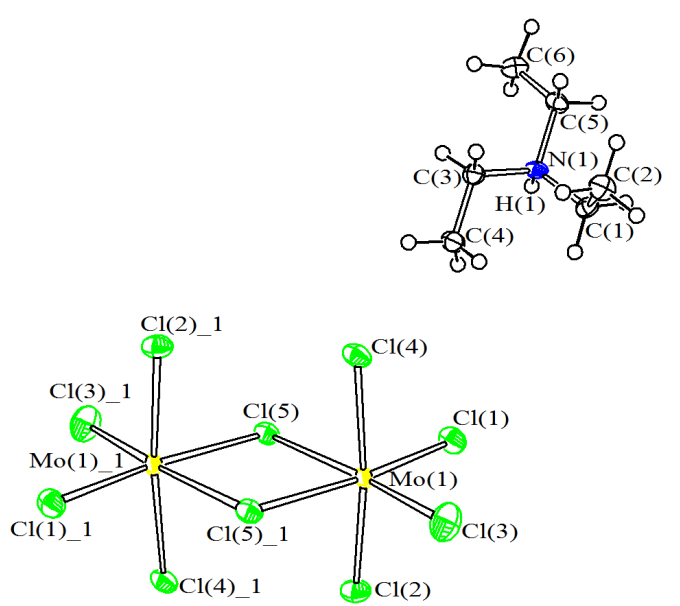

Figure 8. Molecular structure of $\left[\mathrm{NHEt}_{3}\right]_{2}\left[\mathrm{Mo}_{2} \mathrm{Cl}_{10}\right]$, 7, with key atoms labeled. Displacement ellipsoids are at the $50 \%$ probability level. Symmetry transformation used to generate equivalent atoms: $-\mathrm{x}+2,-\mathrm{y}+2,-\mathrm{z}$.

Table 6. Selected bond distances $(\AA)$ and angles $\left({ }^{\circ}\right)$ for 7.

\begin{tabular}{llll}
\hline $\mathrm{Mo}(1)-\mathrm{Cl}(1)$ & $2.312(3)$ & $\mathrm{Mo}(1)-\mathrm{Cl}(2)$ & $2.327(3)$ \\
$\mathrm{Mo}(1)-\mathrm{Cl}(3)$ & $2.229(3)$ & $\mathrm{Mo}(1)-\mathrm{Cl}(4)$ & $2.341(3)$ \\
$\mathrm{Mo}(1)-\mathrm{Cl}(5)$ & $2.584(3)$ & $\mathrm{Mo}(1)-\mathrm{Cl}(5) \_1$ & $2.471(3)$ \\
$\mathrm{N}(1)-\mathrm{C}(1)$ & $1.503(12)$ & $\mathrm{N}(1)-\mathrm{C}(3)$ & $1.511(12)$ \\
$\mathrm{N}(1)-\mathrm{C}(5)$ & $1.527(12)$ & $\mathrm{C}(1)-\mathrm{C}(2)$ & $1.509(13)$ \\
$\mathrm{C}(3)-\mathrm{C}(4)$ & $1.518(13)$ & $\mathrm{C}(5)-\mathrm{C}(6)$ & $1.501(14)$ \\
$\mathrm{Cl}(1)-\mathrm{Mo}(1)-\mathrm{Cl}(5)+1$ & $171.63(10)$ & $\mathrm{Cl}(3)-\mathrm{Mo}(1)-\mathrm{Cl}(5)$ & $174.89(12)$ \\
$\mathrm{Cl}(2)-\mathrm{Mo}(1)-\mathrm{Cl}(4)$ & $172.61(11)$ & $\mathrm{Cl}(5)-\mathrm{Mo}(1)-\mathrm{Cl}(5) \_1$ & $82.25(8)$ \\
$\mathrm{Cl}(1)-\mathrm{Mo}(1)-\mathrm{Cl}(3)$ & $95.69(12)$ & $\mathrm{Mo}(1)-\mathrm{Cl}(5)-\mathrm{Mo}(1) \_1$ & $97.75(8)$ \\
\hline
\end{tabular}

Table 7. Hydrogen bonds for 7.

\begin{tabular}{lcccc}
\hline D-H...A & d(D-H) & $d(H . . . A)$ & $d(D \ldots A)$ & $<$ (DHA) \\
\hline N(1)-H(1)..Cl(2)\#1 & 0.91 & 2.78 & $3.520(9)$ & 138.9 \\
N(1)-H(1)...Cl(4)\#2 & 0.91 & 2.58 & $3.283(8)$ & 134.3 \\
\hline
\end{tabular}

Symmetry transformations used to generate equivalent atoms: $\# 1-\mathrm{x}+1,-\mathrm{y}+2,-\mathrm{z}+1 \quad \# 2 \mathrm{x}, \mathrm{y}, \mathrm{z}+1$.

\section{Reactions of $\mathrm{MoCl}_{5}$ with $\left[\mathrm{MoCl}_{3}\left\{\mathrm{OCH}\left(\mathrm{CF}_{3}\right)_{2}\right\}_{2}\right]$.}

Waldvogel and coworkers previously found that the substitution of chloride ligands in $\mathrm{MoCl}_{5}$ with hexafluoropropoxide moieties supplied superior performances to the resulting metal species in promoting the coupling reactions of arenes. ${ }^{13} \mathrm{We}$ came interested to see whether the same strategy could enhance the activation capability of the molybdenum frame towards amines.

Thus the complex $\left[\mathrm{MoCl}_{3}\left\{\mathrm{OCH}\left(\mathrm{CF}_{3}\right)_{2}\right\}_{2}\right]$, bearing a dinuclear structure analogous to that of $\mathrm{MoCl}_{5}$, was synthesized following the literature procedure. ${ }^{13}$ The reactions of $\left[\mathrm{MoCl}_{3}\left\{\mathrm{OCH}\left(\mathrm{CF}_{3}\right)_{2}\right\}_{2}\right]$ with amines were carried out in the same conditions as those employed for $\mathrm{MoCl}_{5}$. A better conversion of tribenzylamine into the iminium was realized with $\left[\mathrm{MoCl}_{3}\left\{\mathrm{OCH}\left(\mathrm{CF}_{3}\right)_{2}\right\}_{2}\right]$ (Scheme 5). Otherwise, $\left[\mathrm{MoCl}_{3}\left\{\mathrm{OCH}\left(\mathrm{CF}_{3}\right)_{2}\right\}_{2}\right]$ manifested a lower activation power than $\mathrm{MoCl}_{5}$ towards pyrrolidine, in fact only limited conversion to pyrroline was ascertained (Scheme 5). A highly air sensitive solid was isolated from the reaction with $\mathrm{NH}_{2} \mathrm{Cy}$, bearing a magnetic susceptibility value typical for $\mathrm{Mo}(\mathrm{V})$ species. The IR spectrum did not show any intense band around $1240 \mathrm{~cm}^{-1}$ (compare IR spectrum of 5a). These data suggest that the replacement of chloride ligands with hexafluoropropoxide moieties somehow inhibits the generation of the group $\left[\mathrm{Mo}^{\mathrm{VI}}=\mathrm{NCy}\right]$.

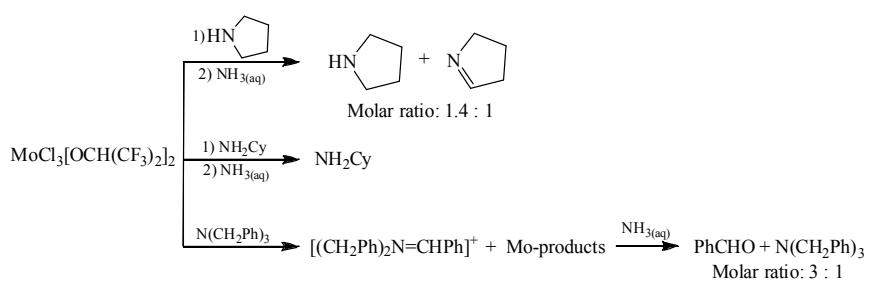

Scheme 5. Reactions of a Mo(V) chloride alkoxide with amines.

\section{Conclusions}

$\mathrm{MoCl}_{5}$ is a commonly known transition metal chloride, that has been increasingly employed in synthetic organic chemistry. We have elucidated the reactions of $\mathrm{MoCl}_{5}$ with a variety of aliphatic amines, some of the reactions showing unusual features. Thus, while high valent metal chlorides generally react with primary and secondary amines via classical aminolysis, electron interchange processes dominate with $\mathrm{MoCl}_{5}$. More in detail, the $\mathrm{Mo}(\mathrm{V})$ centre undergoes single electron reduction by converting a series of secondary amines into the relevant imines. A similar pathway works in the reactions of $\mathrm{MoCl}_{5}$ with trialkylamines, in contrast with previous literature reports. Conversely $\mathrm{Mo}(\mathrm{V})$ to $\mathrm{Mo}(\mathrm{VI})$ oxidation may take place during the interaction of $\mathrm{MoCl}_{5}$ with primary amines, in view of the specific nature of the latter possibly acting as sequential source of one $\mathrm{H}^{+}$cation and one $\mathrm{H}$ atom. Furthermore, although $\mathrm{Et}_{2} \mathrm{NSiMe}_{3}$ has been proved to act as a clean amido group transferor towards $\mathrm{MoCl}_{5}$, such behaviour seems to be strictly dependent on electronic and steric features. Thus, the reaction of $\mathrm{MoCl}_{5}$ with $\mathrm{Me}_{2} \mathrm{NSiMe}_{3}$ proceeds in a non selective way, possibly involving the solvent in the $\mathrm{Cl} / \mathrm{NMe}_{2}$ exchange process. The partial substitution of chloride ligands with hexafluoroisopropoxide groups did not substantially alter the activation capability towards amines of the $\mathrm{Mo}(\mathrm{V})$ centre.

\section{Experimental}

Warning! The metal compounds reported in this paper are highly moisture-sensitive, thus rigorously anhydrous conditions were required for the reaction, crystallization and separation procedures. The reaction vessels were oven dried at $140{ }^{\circ} \mathrm{C}$ prior to use, evacuated $\left(10^{-2} \mathrm{mmHg}\right)$ and then filled with argon. $\mathrm{MoCl}_{5}(99.9 \%)$ was purchased from Strem and stored under argon atmosphere as received. [ $\left.\mathrm{MoCl}_{3}\left\{\mathrm{OCH}\left(\mathrm{CF}_{3}\right)_{2}\right\}_{2}\right]$ was prepared according to the literature procedure. $^{13}$ The organic reactants were commercial products (Apollo Sci., Sigma Aldrich or TCI Europe) of the highest purity available, dried over $\mathrm{P}_{4} \mathrm{O}_{10}$ and stored under argon atmosphere. Solvents were distilled from $\mathrm{P}_{4} \mathrm{O}_{10}$ under argon atmosphere before use. Infrared spectra were recorded at $298 \mathrm{~K}$ on a FT IR-Perkin Elmer Spectrometer, equipped with UATR sampling accessory. Magnetic susceptibilities (reported per Mo atom) were measured at $298 \mathrm{~K}$ on solid samples with a Magway MSB Mk1 magnetic susceptibility balance (Sherwood Scientific Ltd.). Diamagnetic corrections were introduced according to König. ${ }^{45}$ Carbon, hydrogen and nitrogen analyses were performed on a Carlo Erba mod. 1106 instrument. The chloride content was determined by the Mohr method ${ }^{46}$ on solutions prepared by dissolution of the solid in aqueous $\mathrm{KOH}$ at boiling temperature, followed by cooling to room temperature and addition of $\mathrm{HNO}_{3}$ up to neutralization. NMR spectra were recorded at $298 \mathrm{~K}$ on a Bruker Avance II DRX400 instrument equipped with a BBFO broadband probe. The chemical shifts for ${ }^{1} \mathrm{H}$ and ${ }^{13} \mathrm{C}$ were referenced to the non-deuterated aliquot of the solvent, while the chemical shifts for ${ }^{29} \mathrm{Si}$ were referenced to external tetramethylsilane. NMR assignments were assisted by DEPT experiments and ${ }^{1} \mathrm{H},{ }^{13} \mathrm{C}$ correlation measured using gs-HSQC and gs-HMBC experiments. Gas chromatographic analyses were performed at $50{ }^{\circ} \mathrm{C}$ with a Dani 3200 gas chromatograph, equipped with a molecular sieves packed capillary column ( $2 \mathrm{~m} ; 0.25$ in ID), and using argon as the gas carrier $(\mathrm{p}=1.5 \mathrm{~atm})$. GC-MS analyses 
were performed on a HP6890 instrument, interfaced with MSDHP5973 detector and equipped with Phenonex Zebron column.

\section{Reactions of $\mathrm{MoCl}_{5}$ with secondary amines. \\ A) NMR studies.}

A suspension of $\mathrm{MoCl}_{5}(120 \mathrm{mg}, 0.439 \mathrm{mmol})$ in $\mathrm{CH}_{2} \mathrm{Cl}_{2}$ was treated with pyrrolidine $(0.037 \mathrm{~mL}, 0.443 \mathrm{mmol})$. The mixture was allowed to stir at room temperature for $48 \mathrm{~h}$, then the volatile materials were removed in vacuo. An aliquot of the resulting powdery solid underwent magnetic analysis: $\chi_{\mathrm{M}}{ }^{\text {corr }}=1.53 \times 10^{-3}$ cgsu, $\mu_{e f f}=1.92$ BM. The residue was dissolved in $\mathrm{CDCl}_{3}(1 \mathrm{~mL})$, and $\mathrm{NH}_{3(\mathrm{aq})}(40 \%$ $w / w, 3 \mathrm{mmol})$ was added. The mixture was left stirring for $18 \mathrm{~h}$ Then the organic phase was analyzed by NMR spectroscopy. ${ }^{1} \mathrm{H}$ NMR $\left(\mathrm{CDCl}_{3}\right): \delta=7.63\left(\mathrm{~m}, \mathrm{CH}\right.$, pyrroline $\left.{ }^{47}\right), 3.87\left(\mathrm{~m}, \mathrm{CH}_{2}\right.$, pyrroline), $2.88\left(\mathrm{~m}, \mathrm{NCH}_{2}\right.$, pyrrolidine), $2.56\left(\mathrm{~m}, \mathrm{CH}_{2}\right.$, pyrroline), $1.82\left(\mathrm{~m}, \mathrm{CH}_{2}\right.$, pyrroline), $1.71 \mathrm{ppm}\left(\mathrm{m}, \mathrm{CH}_{2}\right.$, pyrrolidine) Approximate pyrroline/pyrrolidine ratio $=5$. The reactions of $\mathrm{MoCl}_{5}$ $(0.50 \mathrm{mmol})$ with one molar equivalent of diethylamine and dibenzylamine, respectively, were carried out by the same procedure described for $\mathrm{MoCl}_{5} /$ pyrrolidine. NMR analyses were as follows. From $\mathrm{MoCl}_{5} / \mathrm{NHEt}_{2}:{ }^{1} \mathrm{H}$ NMR $\left(\mathrm{CDCl}_{3}\right): \delta=9.83\left(\mathrm{q},{ }^{3} \mathrm{~J}_{\mathrm{HH}}=2.93 \mathrm{~Hz}\right.$, $\mathrm{MeCH}=\mathrm{O}) ; 2.24 \mathrm{ppm}\left(\mathrm{d},{ }^{3} \mathrm{~J}_{\mathrm{HH}}=2.93 \mathrm{~Hz}, M e \mathrm{CH}=\mathrm{O}\right)$. From $\mathrm{MoCl}_{5} / \mathrm{NH}\left(\mathrm{CH}_{2} \mathrm{Ph}\right)_{2}:{ }^{1} \mathrm{H} \mathrm{NMR}\left(\mathrm{CDCl}_{3}\right): \delta=9.83\left(\mathrm{q},{ }^{3} \mathrm{~J}_{\mathrm{HH}}=2.93 \mathrm{~Hz}\right.$, $\mathrm{MeCH}=\mathrm{O}) ; 2.24 \mathrm{ppm}\left(\mathrm{d},{ }^{3} \mathrm{~J}_{\mathrm{HH}}=2.93 \mathrm{~Hz}, \quad \mathrm{MeCH}=\mathrm{O}\right)$. $\mathrm{NH}\left(\mathrm{CH}_{2} \mathrm{Ph}\right)_{2} / \mathrm{PhCH}_{2} \mathrm{~N}=\mathrm{CHPh}$ ratio $=$ ca. 1.

\section{B) Isolation of $\left[\mathrm{MoCl}_{5}\left\{\mathrm{NCH}\left(\mathrm{CH}_{2}\right)_{3}\right\}\right], \quad 1, \quad$ and} $\left[\mathrm{CH}_{3} \mathrm{CH}=\mathrm{NHEt}\right]\left[\mathrm{MoOCl}_{4}\right], 2$.

The reaction of $\mathrm{MoCl}_{5}(250 \mathrm{mg}, 0.915 \mathrm{mmol})$ with pyrrolidine $(0.078 \mathrm{~mL}, 0.934 \mathrm{mmol})$ was carried out in dichloromethane $(10 \mathrm{~mL})$ for $48 \mathrm{~h}$. The final solution was filtrated in order to remove some solid, then the solution was concentrated to $3 \mathrm{~mL}$, layered with hexane and stored at $-30{ }^{\circ} \mathrm{C}$. Green crystals of $\mathbf{3}$ suitable for X-ray analysis were recovered after one week. Yield $113 \mathrm{mg}(36 \%)$. Anal Calcd for $\mathrm{C}_{4} \mathrm{H}_{7} \mathrm{Cl}_{5} \mathrm{MoN}$ : C, 14.03; H, 2.06; N, 4.09; Cl, 51.78 . Found: C, 14.20; H, 1.98; N, 4.03; Cl, 51.60. IR (solid state): $1572 \mathrm{~m}$ $(\mathrm{C}=\mathrm{N}) \mathrm{cm}^{-1}$. Magnetic measurement: $\chi_{\mathrm{M}}{ }^{\text {corr }}=9.70 \times 10^{-4} \mathrm{cgsu}, \mu_{e f f}=$ $1.53 \mathrm{BM}$

Crystals of $\mathbf{2}$ were obtained by a procedure analogous to that described for $\mathbf{1}$.

2 (dark yellow crystals). Yield $35 \mathrm{mg}(10 \%)$, from $\mathrm{MoCl}_{5}(293 \mathrm{mg}$, $1.07 \mathrm{mmol})$ and $\mathrm{NHEt}_{2}(0.111 \mathrm{~mL}, 1.07 \mathrm{mmol})$. Anal. Calcd for $\mathrm{C}_{4} \mathrm{H}_{10} \mathrm{Cl}_{4} \mathrm{MoNO}$ : $\mathrm{C}, 14.74 ; \mathrm{H}, 3.09 ; \mathrm{N}, 4.30 ; \mathrm{Cl}, 43.52$. Found: $\mathrm{C}$, 14.57; H, 3.11; N, 4.35; Cl, 43.12. IR (solid state): 1700br $\left(v_{\mathrm{C}=\mathrm{N}}+\right.$ $\left.\delta_{\mathrm{N}-\mathrm{H}}\right), 989 \mathrm{~s}(\mathrm{Mo}=\mathrm{O}) \mathrm{cm}^{-1}$. Magnetic measurement: $\chi_{\mathrm{M}}{ }^{\text {corr }}=$ $9.70 \times 10^{-4}$ cgsu, $\mu_{e f f}=1.53 \mathrm{BM}$.

\section{Reactions of $\mathrm{MoCl}_{5}$ with $\mathrm{N}, \mathrm{N}$-dialkyltrimethylsilylamines.} A) Synthesis and characterization of $\left[\mathrm{MoCl}_{4}\left(\mathrm{NEt}_{2}\right)\right], 3$.

A suspension of $\mathrm{MoCl}_{5}(455 \mathrm{mg}, 1.67 \mathrm{mmol})$ in $\mathrm{CH}_{2} \mathrm{Cl}_{2}(15 \mathrm{~mL})$ was treated with $\mathrm{Et}_{2} \mathrm{NSiMe}_{3}(0.32 \mathrm{~mL}, 1.69 \mathrm{mmol})$, then the mixture was stirred at room temperature for $18 \mathrm{~h}$. The resulting dark solution was filtered in order to remove some solid, then it was eliminated of the volatiles. The residue was washed with pentane $(2 \times 20 \mathrm{~mL})$ and dried in vacuo. Yield $337 \mathrm{mg}(65 \%)$. Anal. Calcd for $\mathrm{C}_{4} \mathrm{H}_{10} \mathrm{Cl}_{4} \mathrm{MoN}$ : C, 15.50; H, 3.25; N, 4.52; Cl, 45.76. Found: C, 15.33; H, 3.12; N, 4.66; Cl, 45.53. IR (solid state): $3068 \mathrm{~m}, 2983 \mathrm{~m}, 1574 \mathrm{~m}, 1452 \mathrm{~m}-\mathrm{s}$, $1424 \mathrm{~m}, 1389 \mathrm{~m}-\mathrm{s}, 1254 \mathrm{~m}-\mathrm{s}, 1193 \mathrm{w}, 1158 \mathrm{w}, 1038 \mathrm{~m}-\mathrm{s}, 842 \mathrm{vs}, 766 \mathrm{~s}$ $\mathrm{cm}^{-1}$. Magnetic measurement: $\chi_{\mathrm{M}}{ }^{\text {corr }}=8.60 \times 10^{-4} \mathrm{cgsu}, \mu_{\text {eff }}=1.44$ BM. In a different experiment, the reaction solution obtained from $\mathrm{MoCl}_{5}$ (ca. $0.5 \mathrm{mmol}$ ) and one equivalent of $\mathrm{Et}_{2} \mathrm{NSiMe}_{3}$ was dried in vacuo. $\mathrm{CDCl}_{3}(1 \mathrm{~mL})$ was added to the residue in air, and the obtained mixture was treated with $\mathrm{NH}_{3(\mathrm{aq})}(40 \% w / w, 0.20 \mathrm{~mL})$. The mixture were left stirring at room temperature for $18 \mathrm{~h}$. NMR analysis on the resulting organic phase evidenced the presence of $\mathrm{NHEt}_{2}$ only $\left[{ }^{1} \mathrm{H} \mathrm{NMR}\left(\mathrm{CDCl}_{3}\right): \delta=2.65\left(\mathrm{~m}, 2 \mathrm{H}, \mathrm{CH}_{2}\right) ; 1.10 \mathrm{ppm}(\mathrm{t}\right.$, $\left.3 \mathrm{H}, \mathrm{CH}_{3}\right) .{ }^{13} \mathrm{C}\left\{{ }^{1} \mathrm{H}\right\}$ NMR $\left(\mathrm{CDCl}_{3}\right): \delta=44.1\left(\mathrm{CH}_{2}\right) ; 15.5 \mathrm{ppm}$ $\left.\left(\mathrm{CH}_{3}\right)\right]$.
B) Isolation of $\left[\mathrm{MoCl}_{3}\left(\mathrm{NMe}_{2}\right)\left(\kappa^{2}-\mathrm{Me}_{2} \mathrm{NCH}_{2} \mathrm{NMe}_{2}\right)\right]$, 4a, and $\left[\mathrm{MoCl}_{3}(\mathrm{NMe})\left(\kappa^{2}-\mathrm{Me}_{2} \mathrm{NCH}_{2} \mathrm{NMe}_{2}\right)\right], 4 \mathrm{~b}$.

A suspension of $\mathrm{MoCl}_{5}(370 \mathrm{mg}, 1.35 \mathrm{mmol})$ in $\mathrm{CH}_{2} \mathrm{Cl}_{2}(15 \mathrm{~mL})$ was treated with $\mathrm{Me}_{2} \mathrm{NSiMe}_{3}(0.22 \mathrm{~mL}, 1.35 \mathrm{mmol})$, then the mixture was stirred at room temperature for $18 \mathrm{~h}$. The resulting dark red solution was eliminated of the volatiles, thus the residue was washed with hexane $(2 \times 20 \mathrm{~mL})$ and dried in vacuo. IR (solid state): $3154 \mathrm{~m}$, $3103 \mathrm{~m}, 2984 \mathrm{~m}, 2932 \mathrm{~m}, 2965 \mathrm{~s}, 2458 \mathrm{~m}, 1596 \mathrm{~m}, 1574 \mathrm{~m}, 1463 \mathrm{vs}$, $1410 \mathrm{~m}, 1258 \mathrm{~m}, 1116 \mathrm{w}, 1027 \mathrm{~m}, 1011 \mathrm{~s}, 949 \mathrm{~m}, 923 \mathrm{w}, 886 \mathrm{~s}, 800 \mathrm{vs}$, $768 \mathrm{w} \mathrm{cm}^{-1}$. Magnetic measurement: $\chi_{\mathrm{M}}{ }^{\text {corr }}=7.35 \times 10^{-4} \mathrm{cgsu}, \mu_{e f f}=$ 1.33 BM. Few crystals of $\mathbf{4 a - b}$ suitable for X-ray analysis were obtained directly from a dichloromethane reaction solution, layered with hexane and settled at $-30{ }^{\circ} \mathrm{C}$.

C) NMR studies. The reaction of $\mathrm{MoCl}_{5}(0.70 \mathrm{mmol})$ with $\mathrm{Me}_{2} \mathrm{NSiMe}_{3}(0.70 \mathrm{mmol})$ was performed also in 1,2-dichloroethane at reflux temperature and in heptane at room temperature. The distinct reaction residues were treated with $\mathrm{CDCl}_{3}(1 \mathrm{~mL})$ and then with $\mathrm{NH}_{3(\mathrm{aq})}(40 \% w / w, 0.20 \mathrm{~mL})$. Dimethylamine was clearly NMR identified in the organic phases after $18 \mathrm{~h}\left({ }^{1} \mathrm{H}: \delta=2.38 \mathrm{ppm} ;{ }^{13} \mathrm{C}: \delta=\right.$ $45.9 \mathrm{ppm}) ;{ }^{48}$ moreover, a significant amount of $\mathrm{Me}_{2} \mathrm{NCH}_{2} \mathrm{CH}_{2} \mathrm{NMe}_{2}$ (ca. 1:1 ratio respect to $\mathrm{Me}_{2} \mathrm{NH}$ ) was found in the mixture obtained from the 1,2-dichloroethane reaction.

\section{Reactions of $\mathrm{MoCl}_{5}$ with primary amines.}

A. Isolation of $\left[\mathrm{MoCl}_{4}(\mathrm{NR})\right]_{2}\left(\mathbf{R}=\mathbf{C y}, \mathbf{5 a} ; \mathbf{B u}^{\mathrm{t}}, \mathbf{5 b}\right)$. General procedure: The appropriate amine was added to $\mathrm{MoCl}_{5}$ in $\mathrm{CH}_{2} \mathrm{Cl}_{2}$ (ca. $20 \mathrm{~mL}$ ) in a Schlenk tube, and the mixture was allowed to stir at room temperature for $48 \mathrm{~h}$. The resulting solution was filtered in order to remove some solid, concentrated to ca. $5 \mathrm{~mL}$, layered with hexane and settled at $-30{ }^{\circ} \mathrm{C}$. Crystals of $\mathbf{5 a}$ and $\mathbf{5 b}$ suitable for Xray analyses were recovered after ca. 1 week.

5a (red solid). Yield $139 \mathrm{mg}$ (38\%), from $\mathrm{MoCl}_{5}$ (300 mg, 1.10 $\mathrm{mmol})$ and $\mathrm{NH}_{2} \mathrm{Cy}(0.126 \mathrm{~mL}, 1.10 \mathrm{mmol})$. Anal. Calcd for $\mathrm{C}_{6} \mathrm{H}_{11} \mathrm{Cl}_{4} \mathrm{MoN}$ : C, 21.52; H, 3.31; N, 4.18; Cl, 42.34. Found: $\mathrm{C}$, 21.37; H, 3.39; N, 4.11; Cl, 42.16. IR (solid state): 2932s, $2856 \mathrm{~m}$, $1448 \mathrm{~s}, 1426 \mathrm{sh}, 1338 \mathrm{~s}, 1291 \mathrm{~s}, 1266 \mathrm{~m}, 1239 \mathrm{~s}(\mathrm{Mo}=\mathrm{N}), 1166 \mathrm{~m}$, $1139 \mathrm{w}, 1099 \mathrm{w}-\mathrm{m}, 1005 \mathrm{~s}, 921 \mathrm{w}-\mathrm{m}, 860 \mathrm{w}-\mathrm{m}, 851 \mathrm{~m}-\mathrm{s}, 793 \mathrm{w}, 736 \mathrm{w}$, $709 \mathrm{w}-\mathrm{m} \mathrm{cm}{ }^{-1}$. Magnetic measurement: diamagnetic. ${ }^{1} \mathrm{H}$ NMR $\left(\mathrm{CD}_{2} \mathrm{Cl}_{2}\right): \delta=5.47(\mathrm{br}, 1 \mathrm{H}, \mathrm{CH}) ; 2.52-2.04\left(\mathrm{~m}, 8 \mathrm{H}, \mathrm{CH}_{2}\right) ; 1.60 \mathrm{ppm}$ $\left(\mathrm{m}, 2 \mathrm{H}, \mathrm{CH}_{2}\right) .{ }^{13} \mathrm{C}\left\{{ }^{1} \mathrm{H}\right\}$ NMR $\left(\mathrm{CD}_{2} \mathrm{Cl}_{2}\right): \delta=86.0(\mathrm{CH}) ; 32.0,24.8$, $23.7 \mathrm{ppm}\left(\mathrm{CH}_{2}\right)$.

5b (dark red solid). Yield $129 \mathrm{mg}$ (43\%), from $\mathrm{MoCl}_{5}(265 \mathrm{mg}$, $0.970 \mathrm{mmol})$ and $\mathrm{NH}_{2} \mathrm{Bu}^{\mathrm{t}}(0.103 \mathrm{~mL}, 0.975 \mathrm{mmol})$. Anal. Calcd for $\mathrm{C}_{4} \mathrm{H}_{9} \mathrm{Cl}_{4} \mathrm{MoN}$ : C, 15.55; H, 2.94; N, 4.53; Cl, 45.91. Found: $\mathrm{C}$, $15.29 ; \mathrm{H}, 3.02 ; \mathrm{N}, 4.38 ; \mathrm{Cl}, 45.70$. Magnetic measurement: diamagnetic.

B. Magnetic analyses and NMR studies. General procedure: $\mathrm{MoCl}_{5}(0.50 \mathrm{mmol})$ and the appropriate amine $(0.50 \mathrm{mmol})$ were allowed to react in $\mathrm{CH}_{2} \mathrm{Cl}_{2}(\mathrm{ca} .20 \mathrm{~mL})$ for $72 \mathrm{~h}$. Thus the volatile materials were removed in vacuo, and the residue was washed with pentane $(2 \times 20 \mathrm{~mL})$. An aliquot of the solid underwent magnetic analysis: from $\mathrm{MoCl}_{5} / \mathrm{NH}_{2} \mathrm{Cy}, \chi_{\mathrm{M}}=7.5 \times 10^{-4} \mathrm{cgsu}$; from $\mathrm{MoCl}_{5} / \mathrm{NH}_{2} \mathrm{Bu}^{\mathrm{t}}, \chi_{\mathrm{M}}=6.7 \times 10^{-4} \mathrm{cgsu}$; from $\mathrm{MoCl}_{5} / \mathrm{NH}_{2}{ }^{\mathrm{i}} \mathrm{Pr}, \chi_{\mathrm{M}}=$ $5.5 \times 10^{-4} \mathrm{cgsu}$; from $\mathrm{MoCl}_{5} / \mathrm{NH}_{2}\left(2,6-\mathrm{C}_{6} \mathrm{H}_{3} \mathrm{Me}_{2}\right), \chi_{\mathrm{M}}=4.2 \times 10^{-4} \mathrm{cgsu}$; from $\mathrm{MoCl}_{5} / \mathrm{NH}_{2} \mathrm{CH}_{2} \mathrm{Ph}, \chi_{\mathrm{M}}=1.0 \times 10^{-3}$ cgsu. Another aliquot (ca. 50 $\mathrm{mg}$ ) was treated with $\mathrm{CDCl}_{3}(1 \mathrm{~mL})$ and then with a large excess of $\mathrm{NH}_{3(\mathrm{aa})}(40 \% \mathrm{w} / \mathrm{w})$. The mixture was left stirring for $18 \mathrm{~h}$, hence the organic phase was analyzed by NMR, showing the presence of the starting amine. A minor amount of $[\mathrm{NH}=\mathrm{CH}(\mathrm{Ph})]$ (about $15 \%$ respect to $\left.\mathrm{NH}_{2} \mathrm{Bz}\right)$ was detected from $\mathrm{MoCl}_{5} / \mathrm{NH}_{2} \mathrm{CH}_{2} \mathrm{Ph}\left[\delta\left({ }^{1} \mathrm{H}\right)=\right.$ $8.35 \mathrm{ppm}(\mathrm{s}, 1 \mathrm{H}, \mathrm{CH})]$.

\section{Reactions of $\mathrm{MoCl}_{5}$ with trialkylamines.}

A) Reaction of $\mathrm{MoCl}_{5}$ with $\mathrm{N}\left(\mathrm{CH}_{2} \mathrm{Ph}\right)_{3}$ : isolation of $\left[\left(\mathbf{C H}_{2} \mathbf{P h}\right)_{2} \mathbf{N}=\mathbf{C H P h}\right]_{2}\left[\mathbf{M o C l}_{\mathbf{6}}\right], \mathbf{6} . \mathrm{MoCl}_{5}(250 \mathrm{mg}, 0.915 \mathrm{mmol})$ was added to a solution of $\mathrm{N}\left(\mathrm{CH}_{2} \mathrm{Ph}\right)_{3}(263 \mathrm{mg}, 0.915 \mathrm{mmol})$ in $\mathrm{CH}_{2} \mathrm{Cl}_{2}$ $(15 \mathrm{~mL})$. The mixture was stirred at room temperature for $18 \mathrm{~h}$. 
Hexane $(80 \mathrm{~mL})$ was added, and the resulting precipitate was separated from the colourless solution, washed with pentane $(2 \times 10$ $\mathrm{mL}$ ) and dried in vacuo. Yield $420 \mathrm{mg}$. IR (solid state): $v=3034 \mathrm{~m}-$ br, 2763w, 1640w-m (C=N, 6), 1595w-m, 1497w-m, 1451s, $1415 \mathrm{~m}$, $1340 \mathrm{w}, 1266 \mathrm{w}, 1214 \mathrm{w}-\mathrm{m}, 1087 \mathrm{w}, 1002 \mathrm{~m}, 990 \mathrm{~m}, 924 \mathrm{~m}, 750 \mathrm{vs}$, $736 \mathrm{~s}-\mathrm{sh}, 697 \mathrm{vs} \mathrm{cm}^{-1}$. Magnetic measurement: $\chi_{\mathrm{M}}{ }^{\text {corr }}=1.29 \times 10^{-3}$ cgsu, $\mu_{e f f}=1.76 \mathrm{BM}$. Anal. Calc. for $\mathrm{C}_{21} \mathrm{H}_{21} \mathrm{Cl}_{5} \mathrm{MoN}$ : Cl, 31.62 . Found: $\mathrm{Cl}, 29.40$. Crystallization from $\mathrm{CH}_{2} \mathrm{Cl}_{2} /$ hexane at $-30^{\circ} \mathrm{C}$ afforded few crystals of $\mathbf{3}$ suitable for $\mathrm{X}$-ray analysis. Anal. Calcd for Anal. Calc. for $\mathrm{C}_{42} \mathrm{H}_{40} \mathrm{Cl}_{6} \mathrm{MoN}_{2}: \mathrm{C}, 57.23 ; \mathrm{H}, 4.57 ; \mathrm{N}, 3.18 ; \mathrm{Cl}$, 24.13. Found: C, 57.11; H, 4.70; N, 3.22; Cl, 23.90. IR (solid state): $v=1640 \mathrm{~s}(\mathrm{C}=\mathrm{N}) \mathrm{cm}^{-1}$.

B) Reaction of $\mathrm{MoCl}_{5}$ with $\mathrm{NEt}_{3}$ : isolation of $\left[\mathrm{NHEt}_{3}\right]_{2}\left[\mathrm{Mo}_{2} \mathrm{Cl}_{10}\right]$, 7. This reaction was performed by using a procedure analogous to that described for $\mathrm{MoCl}_{5} / \mathrm{N}\left(\mathrm{CH}_{2} \mathrm{Ph}\right)_{3}$, from $\mathrm{MoCl}_{5}$ (280 mg, 1.02 mmol) and $\mathrm{NEt}_{3}(0.145 \mathrm{~mL}, 1.04 \mathrm{mmol})$. Yield $298 \mathrm{mg}$ (light-red precipitate). Anal. Calcd for $\mathrm{C}_{6} \mathrm{H}_{15} \mathrm{Cl}_{5} \mathrm{MoN}$ : $\mathrm{Cl}, 47.35$. Found: $\mathrm{Cl}$, 37.05. IR (solid state): $v=3150 \mathrm{~m}(\mathrm{~N}-\mathrm{H}, 7), 3051 \mathrm{w}, 2984 \mathrm{w}-\mathrm{m}$, $2943 \mathrm{w}, 1680 \mathrm{~m}, 1648 \mathrm{~m}, 1452 \mathrm{~s}, 1395 \mathrm{~s}, 1352 \mathrm{~m}, 1287 \mathrm{w}, 1265 \mathrm{~m}$ $1170 \mathrm{w}, 1153 \mathrm{w}, 1103 \mathrm{w}, 1081 \mathrm{w}, 1029,1006 \mathrm{~m}-\mathrm{w}, 832 \mathrm{w}, 804 \mathrm{w}, 786$, $732 \mathrm{vw}, 700 \mathrm{~m}-\mathrm{s} \mathrm{cm}{ }^{-1}$. Magnetic measurement: $\chi_{\mathrm{M}}{ }^{\text {corr }}=1.93 \times 10^{-3}$ cgsu, $\mu_{\text {eff }}=2.16 \mathrm{BM}$. Crystallization from $\mathrm{CH}_{2} \mathrm{Cl}_{2} /$ hexane at $-30^{\circ} \mathrm{C}$ afforded 7 as dark-red crystals suitable for X-ray analysis. Yield 96 mg, 25\%. Anal. Calcd for $\mathrm{C}_{12} \mathrm{H}_{32} \mathrm{Cl}_{10} \mathrm{Mo}_{2} \mathrm{~N}_{2}$ : C, 19.20; $\mathrm{H}, 4.30 ; \mathrm{N}$, 3.73; Cl, 47.22. Found: C, 19.31; H, 4.15; N, 3.52; Cl, 46.98.

C) NMR studies. According to the procedure described above for $\mathrm{MoCl}_{5} /$ pyrrolidine, organic solutions were obtained by allowing the

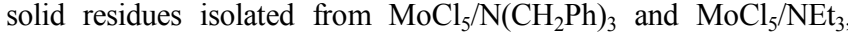
respectively, to react with $\mathrm{CDCl}_{3} / \mathrm{NH}_{3 a q}$ in contact with air. NMR analyses were as follows.

From $\mathrm{MoCl}_{5} / \mathrm{N}\left(\mathrm{CH}_{2} \mathrm{Ph}\right)_{3} .{ }^{1} \mathrm{H} \mathrm{NMR}\left(\mathrm{CDCl}_{3}\right): \delta=10.02(\mathrm{~s}, \mathrm{PhCH}=\mathrm{O})$ 7.90, 7.67-7.36 (Ph); $3.90 \mathrm{ppm}\left[\mathrm{s}, \mathrm{N}\left(\mathrm{CH}_{2} \mathrm{Ph}\right)_{3}\right] .{ }^{13} \mathrm{C} \mathrm{NMR}\left\{{ }^{1} \mathrm{H}\right\}$ $\left(\mathrm{CDCl}_{3}\right): \delta=192.4(\mathrm{PhCH}=\mathrm{O}) ; 139.9,136.7,134.4,129.7,129.1$, $128.5, \quad 128.3, \quad 127.1(\mathrm{Ph}) ; \quad 53.9 \quad \mathrm{ppm} \quad\left[\mathrm{N}\left(\mathrm{CH}_{2} \mathrm{Ph}\right)_{3}\right] . \quad$ Ratio $\mathrm{N}\left(\mathrm{CH}_{2} \mathrm{Ph}\right)_{3} / \mathrm{PhCH}=\mathrm{O} 2: 1$.

From $\mathrm{MoCl}_{5} / \mathrm{NEt}_{3} .{ }^{1} \mathrm{H}$ NMR $\left(\mathrm{CDCl}_{3}\right): \delta=2.43\left[\mathrm{~m}, \mathrm{~N}\left(\mathrm{CH}_{2} \mathrm{CH}_{3}\right)_{3}\right]$; $0.97 \mathrm{ppm}\left[\mathrm{t},{ }^{3} \mathrm{~J}_{\mathrm{HH}}=7.13 \mathrm{~Hz}, \mathrm{~N}\left(\mathrm{CH}_{2} \mathrm{CH}_{3}\right)_{3}\right] .{ }^{3} \mathrm{C} \mathrm{NMR}\left\{{ }^{1} \mathrm{H}\right\}\left(\mathrm{CDCl}_{3}\right): \delta$ $=44.5\left[\mathrm{~N}\left(\mathrm{CH}_{2} \mathrm{CH}_{3}\right)_{3}\right] ; 11.8 \mathrm{ppm}\left[\mathrm{N}\left(\mathrm{CH}_{2} \mathrm{CH}_{3}\right)_{3}\right]$.

\section{Reactions of $\left[\mathrm{MoCl}_{3}\left\{\mathrm{OCH}\left(\mathrm{CF}_{3}\right)_{2}\right\}_{2}\right]$ with amines.}

The reactions of $\mathrm{MoCl}_{3}\left[\mathrm{OCH}\left(\mathrm{CF}_{3}\right)_{2}\right]_{2}$ (ca. $0.80 \mathrm{mmol}$ ) with amines ( 1 molar equivalent) were carried out by using the same conditions described for the corresponding $\mathrm{MoCl}_{5} /$ amine reactions.

A) From $\left[\mathrm{MoCl}_{3}\left\{\mathrm{OCH}\left(\mathrm{CF}_{3}\right)_{2}\right\}_{2}\right]$ and pyrrolidine. Brown solid. IR (solid state): $3185 \mathrm{~m}, 3111 \mathrm{~m}, 2909 \mathrm{w}, 1579 \mathrm{w}, 1461 \mathrm{~m}, 1366 \mathrm{~m}-\mathrm{s}$, $1272 \mathrm{~m}-\mathrm{s}, 1228 \mathrm{~s}, 1214 \mathrm{~s}, 1175 \mathrm{vs}, 1123 \mathrm{~m}, 1102 \mathrm{vs}, 1019 \mathrm{w}, 972 \mathrm{vs}$,

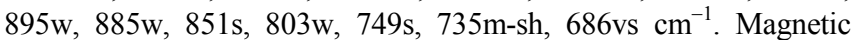
measurement: $\chi_{\mathrm{M}}{ }^{\text {corr }}=9.77 \times 10^{-4}$ cgsu, $\mu_{e f f}=1.53 \mathrm{BM}$. After treatment with $\mathrm{NH}_{3(\mathrm{aq})}$ : pyrroline and pyrrolidine (molar ratio $1.4: 1$ ). B) From $\left[\mathrm{MoCl}_{3}\left\{\mathrm{OCH}\left(\mathrm{CF}_{3}\right)_{2}\right\}_{2}\right]$ and cyclohexylamine. Brown solid. IR (solid state): $3145 \mathrm{~m}-\mathrm{br}, 2939 \mathrm{w}-\mathrm{m}, 2860 \mathrm{w}, 1582 \mathrm{w}-\mathrm{m}, 1477 \mathrm{~m}$, $1451 \mathrm{w}-\mathrm{m}, 1374 \mathrm{w}, 1352 \mathrm{w}, 1282 \mathrm{~s}, 1228 \mathrm{w}-\mathrm{m}, 1184 \mathrm{~s}, 1104 \mathrm{vs}, 1015 \mathrm{~m}$, 991m, 919w, 892m, 857m, 802w, 761m-s, 687vs cm $\mathrm{cm}^{-1}$. Magnetic measurement: $\chi_{\mathrm{M}}{ }^{\text {corr }}=8.53 \times 10^{-4}$ cgsu, $\mu_{\text {eff }}=1.43$ BM. After treatment with $\mathrm{NH}_{3(\mathrm{aq})}$ : cyclohexylamine.

C) From $\left[\mathrm{MoCl}_{3}\left\{\mathrm{OCH}\left(\mathrm{CF}_{3}\right)_{2}\right\}_{2}\right]$ and tribenzylamine. Dark red solid. IR (solid state): 3066w, 3036w, 2962w, 1639m, 1597m, 1497w-m, $1457 \mathrm{~m}, 1379 \mathrm{w}, 1287 \mathrm{~m}, 1260 \mathrm{w}-\mathrm{m}, 1225 \mathrm{~m}, 1216 \mathrm{~m}, 1175 \mathrm{~s}, 1124 \mathrm{w}-\mathrm{m}$, $1100 \mathrm{~s}, 989 \mathrm{~s}, 894 \mathrm{w}, 837 \mathrm{w}, 803 \mathrm{w}, 750 \mathrm{vs}, 734 \mathrm{~m}-\mathrm{s}, 698 \mathrm{vs}, 685 \mathrm{~s} \mathrm{~cm}^{-1}$. Magnetic measurement: $\chi_{\mathrm{M}}{ }^{\text {corr }}=1.47 \times 10^{-3}$ cgsu, $\mu_{\text {eff }}=1.88 \mathrm{BM}$. After treatment with $\mathrm{NH}_{3(\mathrm{aq})}: \mathrm{N}\left(\mathrm{CH}_{2} \mathrm{Ph}\right)_{3}$ and $\mathrm{PhCHO}$ (molar ratio $1: 3)$.

6. GC analyses. Samples for gas chromatographic analyses were prepared as follows: a mixture of $\mathrm{MoCl}_{5}$ (ca. $1 \mathrm{mmol}$ ) and the appropriate amine (1 molar equivalent) in $\mathrm{CH}_{2} \mathrm{Cl}_{2}(10 \mathrm{~mL})$ was stirred at room temperature for $48 \mathrm{~h}$ in a Schlenk tube tapped with a silicon stopper. Then an aliquot of the reaction atmosphere was withdrawn by a $1 \mathrm{~mL}$ syringe through the stopper, and injected into the $\mathrm{GC}$ instrument. The yield of $\mathrm{H}_{2}$ formation was estimated based on analyses of gaseous standard mixtures containing known amounts of $\mathrm{H}_{2}$. From $\mathrm{MoCl}_{5} /$ pyrrolidine: $1 \%$ yield; $\mathrm{MoCl}_{5} / \mathrm{NHEt}_{2}: 1 \%$ yield; from $\mathrm{MoCl}_{5} / \mathrm{NH}_{2} \mathrm{Cy}$ : $2 \%$ yield; from $\mathrm{MoCl}_{5} / \mathrm{NH}_{2} \mathrm{Bu}^{\mathrm{t}}$ : $1 \%$ yield.

7. X-ray Crystallographic Studies. Crystal data and collection details for $\mathbf{1}, \mathbf{2}, \mathbf{4} \cdot 0.5 \mathrm{CH}_{2} \mathrm{Cl}_{2}, \mathbf{5 a}, \mathbf{6} \cdot \mathrm{CH}_{2} \mathrm{Cl}_{2}$ and 7 are listed in Table 8. The diffraction experiments were carried out on a Bruker APEX II diffractometer equipped with a CCD detector and using Mo-K $\alpha$ radiation $(\lambda=0.71073 \AA)$. Data were corrected for Lorentz polarization and absorption effects (empirical absorption correction SADABS). ${ }^{49}$ The structures were solved by direct methods and refined by full-matrix least-squares based on all data using $F^{2}{ }^{50}$ All non-hydrogen atoms were refined with anisotropic displacement parameters. All hydrogen atoms were fixed at calculated positions and refined by a riding model. The crystals of $4 \cdot 0.5 \mathrm{CH}_{2} \mathrm{Cl}_{2}$ are twinned with twin matrix $1000-10000-1$ and refined batch factor $0.1434(12)$. The asymmetric unit of the unit cell of $\mathbf{6} \cdot \mathrm{CH}_{2} \mathrm{Cl}_{2}$ contains one half of a $\left[\mathrm{MoCl}_{6}\right]^{2-}$ anion (located on an inversion centre), one $\left[\left(\mathrm{CH}_{2} \mathrm{Ph}\right)_{2} \mathrm{~N}=\mathrm{CHPh}\right]^{+}$cation (on a general position) and one $\mathrm{CH}_{2} \mathrm{Cl}_{2}$ molecule disordered over two equally populated and symmetry related (by an inversion centre) positions. The $\mathrm{C}$-atoms of the disordered solvent molecule was refined isotropically. The $\mathrm{C}-\mathrm{Cl}$ distances of the $\mathrm{CH}_{2} \mathrm{Cl}_{2}$ molecule were restrained to be $1.75 \AA$ (DFIX command in SHELXL, s.u. 0.02). The asymmetric unit of the unit cell of 7 contains one $\left[\mathrm{NHEt}_{3}\right]^{+}$cation (on a general position) and one half of a $\left[\mathrm{Mo}_{2} \mathrm{Cl}_{10}\right]^{2-}$ anion (on an inversion centre). The crystals are contaminated by the oxide derivative $\left[\mathrm{Mo}_{2}(\mathrm{O})_{2} \mathrm{Cl}_{8}\right]^{2-}$ $(20 \%)$ and this has been included in the final refinement.

\section{Insert Table 8 about here}

Supplementary Material. Figures S1-S2 show DFT-calculated structures, while Table S1 contains the computed relevant bonding parameters for 1. Cartesian coordinates of the DFT-optimized compounds are reported in a separated .xyz file. CCDC reference numbers 1491992 (1), 1491993 (2), $1491991 \quad\left(\mathbf{4} \cdot 1 / 2 \mathrm{CH}_{2} \mathrm{Cl}_{2}\right)$, $1491994(\mathbf{5 a}), 1511406\left(\mathbf{6} \cdot \mathrm{CH}_{2} \mathrm{Cl}_{2}\right)$ and 1511407 (7) contain the supplementary crystallographic data for the X-ray studies reported in this paper. These data can be obtained free of charge at www.ccdc.cam.ac.uk/conts/retrieving.html (or from the Cambridge Crystallographic Data Centre, 12, Union Road, Cambridge CB2 1EZ, UK; fax: (internat.) +44-1223/336-033; e-mail: deposit@ccdc.cam.ac.uk).

8. Computational studies. The computational geometry optimizations were carried out without symmetry constrains, using the hybrid-GGA EDF2 functional ${ }^{51}$ in combination with the 6$31 \mathrm{G}^{* *}$ basis set (ECP-based LANL2DZ basis set for elements beyond $\mathrm{Kr}){ }^{52}$ The "unrestricted" formalism was applied for compounds with unpaired electrons, and the lack of spin contamination was verified by comparing the computed $\left\langle\mathrm{S}^{2}\right\rangle$ values with the theoretical ones. The stationary points were characterized by IR simulations (harmonic approximation), from which zero-point vibrational energies and thermal corrections $(\mathrm{T}=$ $298.15 \mathrm{~K})$ were obtained. ${ }^{53}$ Further optimization of selected geometries was carried out using the range-separated DFT functional $\omega \mathrm{B} 97 \mathrm{X},{ }^{54}$ in combination with the split-valence polarized basis set of Ahlrichs and Weigend. ${ }^{55}$ The C-PCM implicit solvation model $(\varepsilon=9.08)$ was added to $\omega \mathrm{B} 97 \mathrm{X}$ calculations. ${ }^{56}$ The software used for C-PCM/ $\omega$ B97X calculations was Gaussian '09, ${ }^{57}$ while EDF2 calculations were performed with Spartan '08. ${ }^{58}$.

\section{Acknowledgements}


The University of Pisa is acknowledged for financial support. Francesco Del Cima is gratefully acknowledged for the execution of the GC analyses.

\section{References and Notes}

1 Selected recent references: (a) M. Schubert and S. R. Waldvogel, Eur J. Org. Chem., 2016, 1921-1936. (b) Y. Satoh and Y. Obora, Eur. J. Org. Chem., 2015, 5041-5054. (c) C. Redshaw, M. Walton, L. Clowes, D. L. Hughes, A.-M. Fuller, Y. Chao, A. Walton, V. Sumerin, P. Elo, I. Soshnikov, W. Zhao and W.-H. Sun, Chem. Eur. J., 2013, 19, 8884 8899. (d) A. Monassier, V. D’Elia, M. Cokoja, H. Dong, J. D. Pelletier, J.-M. Basset and F. E. Kühn, ChemCatChem, 2013, 5, 1321-1324. (e) S. R. Waldvogel and S. Trosien, Chem. Commun., 2012, 48, 91099119. (f) F. Marchetti and G. Pampaloni, Chem. Commun., 2012, 48 635-653. (g) M. Aresta, A. Dibenedetto, F. Nocito, A. Angelini, B. Gabriele and S. De Negri, Appl. Cat. A: General, 2010, 387, 113-118.

2 (a) F. Yuan, Q. Gu, X. Chen, Y. Tan, Y. Guo and X. Yu, Chem Mater., 2012, 24, 3370-3379. (b) P. Hasan, S. E. Potts, C. J. Carmalt, R. G. Palgrave and H. O. Davies, Polyhedron, 2008, 27, 1041-1048. (c) S. B. Smith and D. W. Stephan, Titanium, in Comprehensive Coordination Chemistry II, (Eds.: J. A. McCleverty and T. J. Meyer), Elsevier, Oxford, 2003, Vol 4, pp. 33-104. (d) E. Hollink and D. W. Stephan, Zirconium and Hafnium, in Comprehensive Coordination Chemistry II, (Eds.: J. A. McCleverty and T. J. Meyer, Elsevier, Oxford, 2003, Vol 4, pp. 105-173. (e) T. S. Lewkebandara, P. H. Sheridan, M. J. Heeg, R. A. Winter and C. H. Winter, Inorg. Chem., 1994, 33, 5879-5889.

3 (a) R. Bondi, F. Marchetti, G. Pampaloni and S. Zacchini, Polyhedron, 2015, 100, 192-198. (b) S. W. Schweiger, D. L. Tillison, M. G. Thorn, P. E. Fanwick and I. P. Rothwell, J. Chem. Soc., Dalton Trans., 2001, 2401-2408. (c) A. V. Korolev, A. L. Rheingold and D. S. Williams, Inorg. Chem., 1997, 36, 2647-2655. (d) K. C. Jayaratne, G. P. A. Yap, B. S. Haggerty, A. L. Rheingold and C. H. Winter, Inorg. Chem., 1996, 35, 4910-4920. (e) M. Polamo and M. Leskelä, J. Chem. Soc. Dalton Trans., 1996, 4345-4349.

4 (a) B. Sharma, S.-J. Chen, J. K. C. Abbott, X.-T. Chen and Z.-L. Xue, Inorg. Chem., 2012, 51, 25-27. (b) X.-H. Zhang, S.-J. Chen, H. Cai, H.J. Im, T. Chen, X. Yu, X. Chen, Z. Lin, Y.-D. Wu and Z.-L. Xue, Organometallics, 2008, 27, 1338-1341. (c) T. Waters, A. G. Wedd, M. Ziolek and I. Nowak, Niobium and Tantalum, in Comprehensive Coordination Chemistry II, (Eds.: J. A. McCleverty and T. J. Meyer), Elsevier, Oxford, 2003, Vol 4, pp. 242-312 (d) D. C. Bradley and I. M. Thomas, Can. J. Chem., 1962, 40, 449-454. (e) D. C. Bradley and I. M. Thomas, Can. J. Chem., 1962, 40, 1355-1360.

5 A. J. Nielson, Polyhedron, 1988, 7, 67-75.

6 A. Merkoulov, S. Schmidt, K. Harms and J. Sundermeyer, Z. Anorg. Allg. Chem., 2005, 631, 1810-1812.

7 (a) M. Bortoluzzi, F. Foschi, F. Marchetti, G. Pampaloni and S Zacchini, Polyhedron, 2016, 115, 30-36. (b) R. Kiesel and E. P. Schram, Inorg. Chem., 1973, 12, 1090-1095. (c) B. J. Brisdon, G. W. A. Fowles and B. P. Osborne, J. Chem. Soc., 1962, 1330-1334.

8 Y. Matsumura, M. Nishimura and H. Hju, J. Org. Chem., 1996, 61, 2809-2812.

9 M. Periasamy, G. Srinivas and P. Bharathi, J. Org. Chem., 1999, 64 4204-4205.

10 P. Bharathi and M. Periasamy, Org. Lett., 1999, 1, 857-859.

11 (a) M. Bortoluzzi, F. Marchetti, G. Pampaloni, C. Pinzino and S. Zacchini, Inorg. Chem., 2016, 55, 887-893. (b) M. Bortoluzzi, F. Marchetti, G. Pampaloni and S. Zacchini, Inorg. Chem., 2014, 53, 3832-3838

12 D. A. Edwards and G. W. Fowles, J. Chem. Soc., 1961, $24-28$.

13 M. Schubert, J. Leppin, K. Wehming, D. Schollmeyer, K. Heinze and S. R. Waldvogel, Angew. Chem. Int. Ed., 2014, 53, $2494-2497$.

14 The treatment of the reaction mixture with a weakly basic water solution facilitates the release of the organic compounds from the highly oxophilic metal products, and allows the spectroscopic identification of the former. As blank experiments, we have made the amines ( 0.5 to $1.5 \mathrm{mmol}$, according to the cases) treated in this work to interact with a mixture of $\mathrm{MoCl}_{5}(0.5 \mathrm{mmol}), \mathrm{CDCl}_{3}(1.5 \mathrm{~mL})$ and $\mathrm{KHCO}_{3}(\mathrm{aq})$ (ca. $10 \mathrm{mmol}$ in $0.3 \mathrm{~mL}$ solution). In general, the amine reactants were the only organic compounds which could be detected in the resulting solutions.
15 S. Dolci, F. Marchetti, G. Pampaloni and S. Zacchini, S. Dalton Trans., 2010, 39, 5367-5376.

16 U. Gellrich, J. R. Khusnutdinova, G. M. Leitus and D. Milstein, J. Am. Chem. Soc., 2015, 137, 4851-4859.

17 (a) D. A. Kuznetsov, I. V. Fedyanin, N. S. Komarova, G. V. Shilov, V. M. Martynenko, S. G. Vasiliev, A. G. Krivenko, K. A. Lyssenko and T. A. Bazhenova, Eur. J. Inorg. Chem., 2015, 715-724. (b) M. Modec and J. V. Brenčič, Eur. J. Inorg. Chem., 2005, 1698-1709. (c) P. Klinzing, A. El-Kholi, U. Muller, K. Dehnicke and K. Findeis, Z. Anorg. Allg. Chem., 1989, 569, 83-90.

18 E. Ferretti, M. Hayatifar, F. Marchetti, G. Pampaloni and S. Zacchini, Polyhedron, 2015, 100, 400-403.

19 (a) W. Xiao, C. Hu and M. D. Ward, Cryst. Growth Des., 2013, 13 , 3197-3200. (b) A. Mores, M. Matziari, F. Beau, P. Cuniasse, A. Yiotakis and V. Dive, J. Med. Chem., 2008, 51, 2216-2226. (c) D. B Rubinov and I. L. Rubinova, Russ. J. Org. Chem., 2004, 40, 11871189.

20 (a) A. D. Garrett, N. J. Vogeley, J. R. Varner, P. S. White and J. L. Templeton, Organometallics, 2006, 25, 1728-1734. (b) M. Ochiai, M. Inenaga, Y. Nagao, R. M. Moriarty, R. K. Vaid and M. P. Duncan, Tetrahedron Lett., 1988, 29, 6917-6920. (c) Y. Nomura, K. Ogawa, Y. Takeuchi and S. Tomoda, Chem. Lett., 1977, 693-696.

21 (a) A. D. Garrett, N. J. Vogeley, J. R. Varner, P. S. White and J. L. Templeton, Organometallics, 2006, 25, 1728-1734. (b) K. Mereiter, M. Morshedi, S. Meghdadi and M. Amirnasr, Refcode FOHXAD, ConQuest Version 1.18, Cambridge Crystallographic Data Centre, 2015. (c) J. L. Garate-Morales and G. J. M. Fernandez, Organometallics, 2004, 23, 3840-3846. (d) G. K. Cantrell, S. J. Geib and T. Y. Meyer, Organometallics, 1999, 18, 4250-4252.

22 J. Campora, I. Matas, P. Palma, E. Alvarez, C. Graiff and A. Tiripicchio, Organometallics, 2007, 26, 3840-3849.

23 K. Yamanouchi, S. Yamada and J. H. Enemark, Inorg. Chim. Acta, 1984, 85, 129-135.

24 (a) B. Cordero, V. Gómez, A. E. Platero-Prats, M. Revés, J. Echevarría, E. Cremades, F. Barragán and S. Alvarez, Dalton Trans., 2008, 2832-2838; (b) F. H. Allen, O. Kennard, D. G. Watson, L. Brammer, A. G. Orpen and R. Taylor, J. Chem. Soc., Perkin Trans. 2 , 1987, S1-S19.

25 O. Knop, T. S. Cameron, P. K. Bakshi, W. Kwiatkowski, S. C. Choi and D. Adhikesavalu, Can. J. Chem., 1993, 71, 1495-1523.

26 F. Marchetti, G. Pampaloni and S. Zacchini, Polyhedron, 2015, 85, 369-375.

27 (a) C. Hammond, M. T. Schümperli and I. Hermans, Chem. Eur. J., 2013, 19, 13193-13198. (b) W. Adam and A. Nikolaus, J. Am. Chem. Soc., 2000, 122, 884-888. (c) S. G. Cohen, A. Parola and G. H. Parsons Jr., Chem. Rev., 1973, 73, 141-161. (d) H. B. Henbest and P. Slade, J. Chem. Soc., 1960, 1558-1560.

28 O. R. Luca, T. Wang, S. J. Konezny, V. S. Batista and R. H. Crabtree, New J. Chem., 2011, 35, 998-999.

29 J. P. Saucedo-Vàzquez, V. M. Ugalde-Saldìvar, A. R. Toscano, P. M. H. Kroneck and M. E. Sosa-Torres, Inorg. Chem., 2009, 48, 12141222.

30 (a) M. Schubert, P. Franzmann, A. Wünsche von Leupoldt, K. Koszinowski, K. Heinze and S. R. Waldvogel, Angew. Chem. Int. Ed., 2016, 55, 1156-1159. (b) J. Leppin, M. Schubert, S. R. Waldvogel and K. Heinze, Chem. Eur. J., 2015, 21, 4229-4232.

31 U. Müller, Angew. Chem. Int. Ed. Engl., 1981, 20, 692-693.

32 (a) R. Haiges, J. A. Boatz, R. Bau, S. Schneider, T. Schroer, M. Yousufuddin and K. O. Christe, Angew. Chem. Int. Ed., 2005, 44, 1860-1865. (b) J. C. Fuggle, D. W. A. Sharp and J. M. Winfield, J. Chem. Soc. Dalton Trans., 1972, 1766-1768.

33 (a) M. Bortoluzzi, G. Bresciani, F. Marchetti, G. Pampaloni and S Zacchini, Dalton Trans., 2015, 44, 10030-10037. (b) M. Bortoluzzi, F. Marchetti, G. Pampaloni and S. Zacchini, Dalton Trans., 2014, 43, 16416-16423. (c) S. Dolci, F. Marchetti, G. Pampaloni and S. Zacchini, Inorg. Chem., 2011, 50, 3846-3848. (d) B. T. Thaker and R. S. Barvalia, J. Coord. Chem., 2010, 63, 1597-1610. (e) D. B. Soria, M. Barquìn, M. J. Gonzalez Garmendia and G. Estiu, J. Coord. Chem., 2008, 61, 3815-3828. (f) J. Beck and M. Koch, Z. Anorg. Allg. Chem., 2006, 632, 756-762. (g) P. Sobota, S. Szafert, J. Utko and T. Lis, $J$ Organomet. Chem., 1992, 423, 195-210.

34 (a) O.-S. Jung, D. H. Jo, Y.-A. Lee, Y. S. Sohn and C. G. Pierpont, Inorg. Chem., 1998, 37, 5875-5880. (b) D. A. Handley, P. B. Hitchcock, T. H. Lee and G. J. Leigh, Inorg. Chim. Acta, 2001, 314, 14-21. (c) P. B. Hitchcock, D. A. Handley, T. H. Lee and G. J. Leigh, 
J. Chem. Soc., Dalton Trans., 2002, 4720-4725. (d) P. J. Heard, P. Sroisuwan and D. A. Tocher, Polyhedron, 2003, 22, 1321-1327.

35 (a) S. Sarkar, A. R. Carlson, M. K. Veige, J. M. Falkowski, K. A Abboud and A. S. Veige, J. Am. Chem. Soc., 2008, 130, 1116-1117. (b) K. Most, N. C. Moesch-Zanetti, D. Vidovic and J. Magull, Organometallics, 2003, 22, 5485-5490. (c) E. Katayev, Y. Li and A. L. Odom, Chem. Commun., 2002, 838-839.

36 (a) D. L. Hughes, D. J. Lowe, M. J. Mohammed, C. J. Pickett and N. M. Pinhal, J. Chem. Soc., Dalton Trans., 1990, 2021-2027. (b) D. Watanabe, S. Gondo, H. Seino and Y. Mizobe, Organometallics, 2007 26, 4909-4920. (c) W. B. Sharp, P. J. Daff, W. S. McNeil and P. Legzdins, J. Am. Chem. Soc., 2001, 123, 6272-6282. (d) J. C. Kim, W. S. Rees Jr. and V. L. Goedken, Inorg. Chem., 1995, 34, 2483-2486.

37 (a) H. Sakamoto, J. Ishikawa and M. Otomo, Bull. Chem. Soc. Jpn., 1995, 68, 2831-2836. (b) H. Yang and F. C. Thyrion, Int. J. Chem. Kinet., 1994, 26, 309-315.

38 M. L. H. Green, P. C. Konidaris and P. Mountford, J. Chem. Soc Dalton Trans., 1994, 2975-2982.

39 (a) C. Lorber, Coord. Chem. Rev., 2016, 308, 76-96. (b) J. C. Axtell, R. R. Schrock, P. Müller, S. J. Smith and A. H. Hoveyda, Organometallics, 2014, 33, 5342-5348. (c) H. R. Bigmore, M. A. Zuideveld, R. M. Kowalczyk, A. R. Cowley, M. Kranenburg and E. J. L. McInnes, Inorg. Chem., 2006, 45, 6411-6423. (d) M. L. H. Green, P. C. Konidaris, P. Mountford and S. J. Simpson, J. Chem. Soc., Chem. Commun., 1992, 256-259. (e) R. Toreki, R. R. Schrock and W. M. Davis, J. Am. Chem. Soc., 1992, 114, 3367-3380.

40 L. W. Francisco, P. S. White and J. L. Templeton, Organometallics, 1997, 16, 2547-2555.

41 M. M. Hänninen, R. Sillanpää, H. Kiveläb and A. Lehtonen, Dalton Trans., 2011, 40, 2868-2874.

42 (a) T. S. Pilyugina, R. R. Schrock, A. S. Hock and P. Müller, Organometallics, 2005, 24, 1929-1937. (b) C. Y. Chou, J. C. Huffman and E. A. Maatta, J. Chem. Soc. Chem. Commun., 1984, 1184-1185.

43 W. P. Griffith, B. Reddy, A. G. F. Shoair, M. Suriaatmaja, A. J. P. White and D. J. Williams, J. Chem. Soc., Dalton Trans., 1998, 28192825 .

44 E. Hey, F. Weller and K. Dehnicke, Z. Anorg. Allg. Chem., 1984, 508, 86-92.

45 E. König, Magnetische Eigenschaften der Koordinations- und Metallorganischen Verbindungen der Übergangselemente in LandoltBörnstein, Zahlenwerte und Funktionen aus Naturwissenschaften und Technik, 6th Ed., Springer-Verlag, Berlin, Göttingen, Heidelberg, $1966,2,16$.

46 D. A. Skoog, D. M. West and F. J. Holler, Fundamentals of Analytical Chemistry, 7th Edition, Thomson Learning, Inc, USA, 1996.

47 J.-C. Guillemin, J.-M. Denis, R. M.-C. Lasne and J.-L. Ripoll, Tetrahedron, 1988, 44, 4447-4455.

48 I. Alkorta and J. A. Elguero, J. Magn. Reson. Chem., 2004, 42, 955-961.

49 G. M. Sheldrick, SADABS, Program for empirical absorption correction, University of Göttingen, Göttingen, Germany, 1996.

50 (a) G. M. Sheldrick, SHELX97, Program for crystal structure determination, University of Göttingen, Germany, 1997; (b) G. M. Sheldrick, Acta Crystallogr. 2015, 3, A71 (c) G. M. Sheldrick, Acta Crystallogr. 2015, 3, C71.

51 C. Y. Lin, M. W. George, P. M. W. Gill, Aust. J. Chem., 2004, 57, $365-$ 370 .

52 (a) M. Dolg, Modern Methods and Algorithms of Quantum Chemistry, J. Grotendorst Ed., John Neumann Institute for Computing, NIC series, Jülich, 2000, 1, 479. (b) P. J. Hay and W. R. Wadt, J. Chem. Phys., 1985, 82, 270-283. (c) P. J. Hay and W. R. Wadt, J. Chem. Phys., 1985, 82, 299-310. (d) W. J. Henre, R. Ditchfield and J. A. Pople, J. Chem. Phys., 1972, 56, 2257-2261.

53 C. J. Cramer, Essentials of Computational Chemistry, 2nd Edition, Wiley, Chichester, 2004.

54 (a) Yu. Minenkov, Å. Singstad, G. Occhipinti and V. R. Jensen, Dalton Trans., 2012, 41, 5526-5541. (b) J.-D. Chai and M. Head-Gordon, Phys. Chem. Chem. Phys., 2008, 10, 6615-6620. (c) I. C. Gerber and J. C. Ángyán, Chem. Phys. Lett., 2005, 415, 100-105.

55 F. Weigend and R. Ahlrichs, Phys. Chem. Chem. Phys., 2005, 7, $3297-$ 3305.

56 (a) M. Cossi, N. Rega, G. Scalmani and V. Barone, J. Comput. Chem., 2003, 24, 669-681. (b) V. Barone and M. Cossi, J. Phys. Chem. A, 1998, 102, 1995-2001.

57 Gaussian 09, Revision C.01, M. J. Frisch et al., Gaussian, Inc., Wallingford CT, 2010.
58 Spartan '08, version 1.1.1, Wavefunction, Inc., Irvine CA, 2009. Except for molecular mechanics and semi-empirical models, the calculation methods used in Spartan have been documented in: Y. Shao et al. Advances in methods and algorithms in a modern quantum chemistry program package. Phys. Chem. Chem. Phys., 2006, 8, 3172-3191. 
Table 8. Crystal data and measurement details for $\mathbf{1 , 2}, \mathbf{4} \cdot \frac{1}{2} \mathrm{CH}_{2} \mathrm{Cl}_{2}, \mathbf{5 a}, \mathbf{6} \cdot \mathrm{CH}_{2} \mathrm{Cl}_{2}$ and 7 .

\begin{tabular}{|c|c|c|c|c|c|c|}
\hline & 1 & 2 & $4 \cdot 1 / 2 \mathrm{CH}_{2} \mathrm{Cl}_{2}$ & $5 a$ & 6. $\mathrm{CH}_{2} \mathrm{Cl}_{2}$ & 7 \\
\hline Formula & $\mathrm{C}_{4} \mathrm{H}_{7} \mathrm{Cl}_{5} \mathrm{MoN}$ & $\mathrm{C}_{8} \mathrm{H}_{20} \mathrm{Cl}_{8} \mathrm{Mo}_{2} \mathrm{~N}_{2} \mathrm{O}_{2}$ & $\mathrm{C}_{14} \mathrm{H}_{39} \mathrm{Cl}_{8} \mathrm{Mo}_{2} \mathrm{~N}_{6}$ & $\mathrm{C}_{12} \mathrm{H}_{22} \mathrm{Cl}_{8} \mathrm{Mo}_{2} \mathrm{~N}_{2}$ & $\mathrm{C}_{43} \mathrm{H}_{42} \mathrm{Cl}_{8} \mathrm{MoN}_{2}$ & $\mathrm{C}_{12} \mathrm{H}_{32} \mathrm{Cl}_{9.6} \mathrm{Mo}_{2} \mathrm{~N}_{2} \mathrm{O}_{0.4}$ \\
\hline FW & 342.30 & 651.74 & 766.99 & 669.80 & 966.33 & 742.99 \\
\hline $\mathrm{T}, \mathrm{K}$ & $100(2)$ & $100(2)$ & $100(2)$ & $100(2)$ & $100(2)$ & $100(2)$ \\
\hline$\lambda, \AA$ & 0.71073 & 0.71073 & 0.71073 & 0.71073 & 0.71073 & 0.71073 \\
\hline Crystal system & Orthorhombic & Monoclinic & Monoclinic & Triclinic & Monoclinic & Orthorhombic \\
\hline Space group & $\operatorname{Pna2}_{1}$ & $P 2_{1} / n$ & $P 2_{1} / c$ & $P \mathbf{1}$ & $P 2_{1} / c$ & Pbca \\
\hline$a, \AA$ & $11.8263(17)$ & $8.449(3)$ & $7.9913(5)$ & $6.6315(17)$ & $10.0833(9)$ & $13.8611(7)$ \\
\hline$b, \AA$ & $8.2825(12)$ & $13.113(4)$ & $27.2271(8)$ & $7.648(2)$ & $13.2029(10)$ & $13.6266(7)$ \\
\hline$c, \AA$ & $10.2388(15)$ & $9.937(3)$ & $13.7004(8)$ & $11.839(3)$ & $16.6033(12)$ & $14.1240(6)$ \\
\hline$\alpha,^{\circ}$ & 90 & 90 & 90 & $106.915(2)$ & 90 & 90 \\
\hline$\beta,^{\circ}$ & 90 & $102.064(3)$ & $90.321(4)$ & $96.903(3)$ & $103.818(6)$ & 90 \\
\hline$\gamma,^{\circ}$ & 90 & 90 & 90 & $102.798(3)$ & 90 & 90 \\
\hline Cell Volume, $\AA^{3}$ & $1002.9(3)$ & $1076.6(6)$ & $2980.9(3)$ & $549.1(2)$ & $2146.4(3)$ & $2667.7(2)$ \\
\hline $\mathrm{Z}$ & 4 & 2 & 4 & 1 & 2 & 4 \\
\hline$D_{c}, \mathrm{~g} \cdot \mathrm{cm}^{-3}$ & 2.267 & 2.011 & 1.079 & 2.026 & 1.495 & 1.850 \\
\hline$\mu, \mathrm{mm}^{-1}$ & 2.577 & 2.161 & 1.574 & 2.115 & 0.837 & 1.907 \\
\hline $\mathrm{F}(000)$ & 660 & 636 & 1540 & 328 & 948 & 1474 \\
\hline Crystal size, $\mathrm{mm}$ & $0.19 \times 0.16 \times 0.12$ & $0.19 \times 0.12 \times 0.10$ & $0.19 \times 0.15 \times 0.10$ & $0.19 \times 0.16 \times 0.12$ & $0.14 \times 0.12 \times 0.10$ & $0.18 \times 0.16 \times 0.13$ \\
\hline$\theta$ (limits) $)^{\circ}$ & $3.00-26.99$ & $2.61-27.00$ & $0.75-26.00$ & $1.83-27.00$ & $1.99-25.02$ & $2.54-27.00$ \\
\hline Reflections collected & 10237 & 11565 & 34636 & 6004 & 30144 & 30112 \\
\hline Independent reflections & $2180\left[R_{\mathrm{int}}=0.0392\right]$ & $2351\left[R_{\mathrm{int}}=0.0489\right]$ & $5833\left[R_{\mathrm{int}}=0.0613\right]$ & $2382\left[R_{\mathrm{int}}=0.0385\right]$ & $3791\left[R_{\text {int }}=0.2415\right]$ & $2888\left[R_{\text {int }}=0.0282\right]$ \\
\hline Data / restraints /parameters & $2180 / 1 / 100$ & $2351 / 0 / 100$ & $5833 / 0 / 272$ & $2382 / 0 / 109$ & $3791 / 2 / 253$ & $2888 / 0 / 124$ \\
\hline Goodness on fit on $\mathrm{F}^{2}$ & 1.083 & 1.041 & 1.063 & 1.093 & 0.970 & 1.212 \\
\hline$R_{1}(I>2 \sigma(I))$ & 0.0227 & 0.0278 & 0.0461 & 0.0317 & 0.0627 & 0.0803 \\
\hline$w R_{2}$ (all data) & 0.0398 & 0.0682 & 0.1092 & 0.0760 & 0.1378 & 0.1913 \\
\hline Largest diff. peak and hole, e $\AA^{-3}$ & $0.416 /-0.480$ & $0.756 /-0.615$ & $1.293 /-0.724$ & $0.882 /-0.765$ & $0.530 /-1.061$ & $2.147 /-2.430$ \\
\hline
\end{tabular}

